\title{
Cytokine-mediated activation of human ex vivo-expanded Vy9Vס2 T cells
}

\author{
Eisuke Domae ${ }^{1}$, Yuya Hirai' ${ }^{2}$, Takashi Ikeo ${ }^{1}$, Seiji Goda ${ }^{3}$ and Yoji Shimizu ${ }^{4}$ \\ ${ }^{1}$ Department of Biochemistry, Osaka Dental University, Hirakata, Osaka 5731121, Japan \\ ${ }^{2}$ Department of Biology, Osaka Dental University, Hirakata, Osaka 5731121, Japan \\ ${ }^{3}$ Department of Oral Science, Graduate School of Dentistry, Kanagawa Dental University, Yokosuka, Kanagawa 2388580, \\ Japan \\ ${ }^{4}$ Department of Laboratory Medicine and Pathology, Center for Immunology, Masonic Cancer Center, University of Minnesota \\ Medical School, Minneapolis, Minnesota 55455, USA
}

Correspondence to: Eisuke Domae, email: domae-ei@cc.osaka-dent.ac.jp

Keywords: $\gamma \delta$ T cells, IL-12/IL-18, IKBל, STAT4, NF-KB p65

Received: May 20, $2016 \quad$ Accepted: April 07, $2017 \quad$ Published: April 28, 2017

Copyright: Domae et al. This is an open-access article distributed under the terms of the Creative Commons Attribution License 3.0 (CC BY 3.0), which permits unrestricted use, distribution, and reproduction in any medium, provided the original author and source are credited.

\section{ABSTRACT}

VY9Vठ2 T cells, the major subset of the human peripheral blood y $\mathrm{T}$-cell, respond to microbial infection and stressed cells through the recognition of phosphoantigens. In contrast to the growing knowledge of antigen-mediated activation mechanisms, the antigen-independent and cytokine-mediated activation mechanisms of Vy9Vס2 T cells are poorly understood. Here, we show that interleukin (IL) -12 and IL-18 synergize to activate human ex vivo-expanded $\mathrm{VY} 9 \mathrm{~V} \delta 2 \mathrm{~T}$ cells. $\mathrm{VY9V \delta 2} \mathrm{T} \mathrm{cells} \mathrm{treated} \mathrm{with}$ IL-12 and IL-18 enhanced effector functions, including the expression of IFN-Y and granzyme B, and cytotoxicity. These enhanced effector responses following IL-12 and IL-18 treatment were associated with homotypic aggregation, enhanced expression of ICAM-1 and decreased expression of the B- and T-Iymphocyte attenuator (BTLA), a coinhibitory receptor. IL-12 and IL-18 also induced the antigen-independent proliferation of VY9Vס2 T cells. Increased expression of IKBZ, IL-12Rß2 and IL-18Ra following IL-12 and IL-18 stimulation resulted in sustained activation of STAT4 and NF-KB. The enhanced production of IFN-Y and cytotoxic activity are critical for cancer immunotherapy using VY9Vठ2 T cells. Thus, the combined treatment of ex vivo-expanded $V_{Y} 9 \mathrm{~V} \delta 2 \mathrm{~T}$ cells with IL-12 and IL-18 may serve as a new strategy for the therapeutic activation of these cells.

\section{INTRODUCTION}

Human $\mathrm{V} \gamma 9 \mathrm{~V} \delta 2 \mathrm{~T}$ cells predominate in the population of peripheralblood $\gamma \delta$ Tcellsandplayakeyroleinimmunityagainst microbial infection and tumors [1]. The $\mathrm{V} \gamma 9 \mathrm{~V} \delta 2 \mathrm{~T}$ cell receptor (TCR) recognizes a conformational change in butyrophilin $3 \mathrm{~A} 1$ induced by the association with phosphoantigens such as isopentenyl pyrophosphate (IPP) [2-5]. IPP is produced as an intermediate of the mevalonate pathway, and the dysregulation of this pathway in transformed cells or the pharmacological inhibition by aminobisphosphonate causes an accumulation of IPP in tumor cells, which leads to their killing by activated V $\gamma 9$ V 82 T cells [6].
$\mathrm{V} \gamma 9 \mathrm{~V} \delta 2 \mathrm{~T}$ cells express natural-killer group 2, member D (NKG2D) and recognize stress-induced self ligands such as MHC class I-related chains A and B (MICA/B) and UL16 binding proteins (ULBPs) [7]. Co-stimulation by these ligands through NKG2D enhances $\mathrm{V} \gamma 9 \mathrm{~V} \delta 2 \mathrm{~T}$ cell-mediated cytotoxicity against tumor cells [7]. In concert with TCR and NK-receptor stimulation, inflammatory cytokines such as IL-12 and IL-18 provide a critical signal to promote effector functions such as cytotoxicity and IFN- $\gamma$ expression and enhance the clonal expansion of $\mathrm{V} \gamma 9 \mathrm{~V} \delta 2 \mathrm{~T}$ cells [8-11].

In conventional $\alpha \beta \mathrm{T}$ cells and NK cells, antigenindependent, cytokine-mediated activation serves as an alternative regulatory mechanism. In $\mathrm{CD} 8^{+} \mathrm{T}$ cells, antigenindependent activation mediated by combined exposure to IL- 
12 and IL-18 is an important aspect of their sentinel response to a local microbial infection before the development of the adaptive immune response [12]. The most intensely studied effect of IL-12 and IL-18 on CD8 ${ }^{+} \mathrm{T}$ cells is the profound induction of IFN- $\gamma$, and the combined treatment of IL-12 and IL-18 induces proliferation of virus-specific memory $\mathrm{CD}^{+} \mathrm{T}$ cells [13]. NK cells are also a target of IL-12 and IL-18 [14], and the presence of these cytokines might be critical for controlling MHC class I-deficient tumors [15]. Thus, the antigen-independent, cytokine-mediated activation of lymphocytes is an important mechanism that regulates adaptive and innate immunity.

In contrast to the growing knowledge regarding antigen-mediated activation mechanisms of $\mathrm{V} \gamma 9 \mathrm{~V} \delta 2 \mathrm{~T}$ cells, knowledge regarding antigen-independent and cytokinemediated activation mechanisms is considerably less. In the present study, we examine the alternate activation mechanisms of human ex vivo-expanded $\mathrm{V} \gamma 9 \mathrm{~V} \delta 2 \mathrm{~T}$ cells using inflammatory and homeostatic cytokines. We demonstrate that $\mathrm{V} \gamma 9 \mathrm{~V} \delta 2 \mathrm{~T}$ cells produce IFN- $\gamma$ and upregulate activation markers in response to combined exposure to IL-12 and IL-18. Moreover, combined exposure to IL-12 and IL-18 induced the proliferation of $\mathrm{V} \gamma 9 \mathrm{~V} \delta 2 \mathrm{~T}$ cells independent of antigen, which was enhanced upon subsequent exposure to IL-2 or IL-15. Further, cytokine-activated $\mathrm{V} \gamma 9 \mathrm{~V} \delta 2 \mathrm{~T}$ cells produced higher levels of granzyme B and efficiently killed tumor cells. Finally, our results address the induction of $\mathrm{I} \kappa \mathrm{B} \zeta$ and the sustained activation of STAT4 and NF- $\kappa$ B as pivotal mechanisms for the IL-12/IL-18-induced activation of $\mathrm{V} \gamma 9 \mathrm{~V} \delta 2 \mathrm{~T}$ cells.

\section{RESULTS}

\section{$\mathrm{V} \gamma 9 \mathrm{~V} \delta 2 \mathrm{~T}$ cells produce IFN- $\gamma$ in response to combined exposure to IL-12 and IL-18}

The synergistic effect of IL-12 and IL-18 on IFN- $\gamma$ production by NK and $\alpha \beta$ T cells is well established and may have a pathophysiological role [13, 14]. Although ex vivo-expanded $\mathrm{V} \gamma 9 \mathrm{~V} \delta 2 \mathrm{~T}$ cells produce IFN $-\gamma$ in response to phosphoantigen [16], to the best of our knowledge, there are no studies that show whether $\mathrm{V} \gamma 9 \mathrm{~V} \delta 2 \mathrm{~T}$ cells produce IFN- $\gamma$ in response to combined exposure to IL-12 and IL-18. To address this question, we treated $\mathrm{V} \gamma 9 \mathrm{~V} \delta 2 \mathrm{~T}$ cells with IL12 , IL-18, or both for $16 \mathrm{~h}$ and then tested for intracellular IFN- $\gamma$. Although IL-12 or IL-18 alone did not induce detectable production of IFN- $\gamma$, combined treatment with IL-12 and IL-18 considerably induced IFN- $\gamma$ production in ex vivo-expanded $\mathrm{V} \gamma 9 \mathrm{~V} \delta 2 \mathrm{~T}$ cells (Figure 1A).

Next, to determine whether the ability of cytokines to induce robust expression of IFN- $\gamma$ in $\mathrm{V} \gamma 9 \mathrm{~V} \delta 2 \mathrm{~T}$ cells is unique for the combination of IL-12 and IL-18, we treated ex vivoexpanded $\mathrm{V} \gamma 9 \mathrm{~V} \delta 2 \mathrm{~T}$ cells with combinations of cytokines including IL-2, IL-12, IL-15, and IL-18. Although treatment with IL-2 alone, IL-2/IL-12, or IL-12/IL-15 induced IFN- $\gamma$ production, the duration and intensity was limited compared with IL-12/IL-18-induced IFN- $\gamma$ production(Figure 1B). Thus, the combination of IL-12 and IL-18 is a highly potent activator of ex vivo-expanded $\mathrm{V} \gamma 9 \mathrm{~V} \delta 2 \mathrm{~T}$ cells.

Because the $\mathrm{V} \gamma 9 \mathrm{~V} \delta 2 \mathrm{~T}$ cells used in these experiments were pre-activated in the process of expansion by IL-2 and zoledronic acid, we next examined whether freshly isolated human $\mathrm{V} \gamma 9 \mathrm{~V} \delta 2 \mathrm{~T}$ cells also produce IFN- $\gamma$ in response to IL-12 and IL-18. Although the percentage of IFN- $\gamma$ positive cells was not high as seen in ex vivoexpanded $\mathrm{V} \gamma 9 \mathrm{~V} \delta 2 \mathrm{~T}$ cells, combined treatment of IL12 and IL-18 also induced IFN- $\gamma$ production in freshly isolated human $\mathrm{V} \gamma 9 \mathrm{~V} \delta 2 \mathrm{~T}$ cells (Figure 1C). Freshly isolated $\mathrm{V} \gamma 9 \mathrm{~V} \delta 2 \mathrm{~T}$ cells are a heterogeneous population of naïve cells and antigen experienced cells (Supplementary Figure 1). To determine if previous antigen exposure affects IFN- $\gamma$ production in $\mathrm{V} \gamma 9 \mathrm{~V} \delta 2 \mathrm{~T}$ cells, we analyzed cell surface expression of CD27 and CD45RA in IL12/IL-18 treated freshly isolated V $\gamma 9 \mathrm{~V} \delta 2 \mathrm{~T}$ cells. We did not observe significant differences between naïve $\left(\mathrm{CD} 27^{+} \mathrm{CD} 45 \mathrm{RA}^{+}\right)$phenotype population and antigen experienced populations (Figure 1D). These results show that combined exposure to IL-12 and IL-18 induces IFN- $\gamma$ expression in $\mathrm{V} \gamma 9 \mathrm{~V} \delta 2 \mathrm{~T}$ cells, and the pre-activation of $\mathrm{V} \gamma 9 \mathrm{~V} \delta 2 \mathrm{~T}$ cells during ex vivo expansion results in enhanced IFN- $\gamma$ production in response to these cytokines.

\section{IL-12 and IL-18 synergize to induce the proliferation of ex vivo-expanded $\mathrm{V} \gamma 9 \mathrm{~V} \delta 2 \mathrm{~T}$ cells}

Upon antigen stimulation, lymphocytes start producing effector molecules, change their pattern of expression of cell-surface activation markers, and start proliferating [17]. Further, IL-12 and IL-18 treatment induces the proliferation of murine virus-specific $\mathrm{CD}^{+}$memory $\mathrm{T}$ cells without antigen stimulation [13]. We hypothesized that IL-12/IL-18 treatment might also induce $\mathrm{V} \gamma 9 \mathrm{~V} \delta 2 \mathrm{~T}$ cells to proliferate. Therefore, we assessed cytokine-mediated $\mathrm{V} \gamma 9 \mathrm{~V} \delta 2 \mathrm{~T}$ cell proliferation using the CellTrace Violet (CTV) dilution assay. Similar to virus-specific $\mathrm{CD} 8^{+}$memory $\mathrm{T}$ cells, treatment with IL-12/IL-18 induced the proliferation of ex vivo-expanded $\mathrm{V} \gamma 9 \mathrm{~V} \delta 2 \mathrm{~T}$ cells in the absence of antigen stimulation (Figure 2A). Treatment with IL-12 or IL-18 alone did not induce the proliferation of $\mathrm{V} \gamma 9 \mathrm{~V} \delta 2 \mathrm{~T}$ cells (Figure $2 \mathrm{~A}$ ).

Cytokines that engage common cytokine receptor $\gamma$-chains play crucial roles in the survival and proliferation of lymphocytes [18]. We therefore determined the ability of IL-12/IL-18-activated V $\gamma 9 \mathrm{~V} \delta 2 \mathrm{~T}$ cells to proliferate in the presence of low concentrations of IL-2 $(10 \mathrm{U} / \mathrm{mL}), \mathrm{IL}-7$ $(1 \mathrm{ng} / \mathrm{mL})$, or IL-15 $(1 \mathrm{ng} / \mathrm{mL})$. IL-2 and IL-15, but not IL-7, enhanced the proliferation of IL-12/IL-18-activated $\mathrm{V} \gamma 9 \mathrm{~V} \delta 2 \mathrm{~T}$ cells (Figure 2B).

Next, we examined the effect of IL-12 and IL-18 on the proliferation of freshly isolated $\mathrm{V} \gamma 9 \mathrm{~V} \delta 2 \mathrm{~T}$ cells. Although anti-CD3 and anti-CD28 treated positive control cells induced CTV dilution, IL-12/IL-18 treatment did not induce CTV dilution in freshly isolated $\mathrm{V} \gamma 9 \mathrm{~V} \delta 2 \mathrm{~T}$ cells. Thus, in contrast to the induction of IFN- $\gamma$, the proliferation 
of freshly isolated $\mathrm{V} \gamma 9 \mathrm{~V} \delta 2 \mathrm{~T}$ cells is not induced by the combined treatment of IL-12 and IL-18 (Figure 2C).

These results suggest that IL-12 and IL-18 program ex vivo-expanded $\mathrm{V} \gamma 9 \mathrm{~V} \delta 2 \mathrm{~T}$ cells to proliferate and that this effect is further enhanced by subsequent exposure to IL-2 or IL-15.

\section{Ex vivo-expanded $\mathrm{V} \gamma 9 \mathrm{~V} \delta 2 \mathrm{~T}$ cells treated with IL-12 and IL-18 express increased levels of effector molecules and decreased levels of co- inhibitory receptors}

Antigen-dependent stimulation of T cells is associated with the induction of integrin-mediated adhesion and enhanced expression of adhesion molecules. We examined the ability of IL-12 and IL-18 to enhance the effector function of ex vivo-expanded $\mathrm{V} \gamma 9 \mathrm{~V} \delta 2 \mathrm{~T}$ cells and observed that treatment with IL-12 and IL-18 resulted in the induction of robust homotypic aggregates (Figure 3A). The formation of these aggregates upon treatment with IL-12 and IL-18 was associated with increased levels of ICAM-1 compared with untreated-, IL-12- or IL-18-treated cells (Figure 3B).

Next, to determine whether cytokine treatment influenced other markers of $\mathrm{V} \gamma 9 \mathrm{~V} \delta 2 \mathrm{~T}$-cell activation, we measured the levels of CD25. Cells treated with IL-12 and IL-18 expressed increased levels of CD25 compared with cells treated with medium, IL-12, or IL-18 (Figure 3C).

The co-inhibitory receptor BTLA is expressed by resting $\mathrm{V} \gamma 9 \mathrm{~V} \delta 2 \mathrm{~T}$ cells, and TCR-mediated activation downregulates its expression on the cell surface [9]. To determine whether ex vivo-expanded $\mathrm{V} \gamma 9 \mathrm{~V} \delta 2 \mathrm{~T}$ cells express BTLA and whether cytokine-mediated activation affects its cell-surface expression, we analyzed BTLA expression by $\mathrm{V} \gamma 9 \mathrm{~V} \delta 2 \mathrm{~T}$ cells treated with medium, IL-12, IL-18, or a combination of both cytokines. More than $40 \%$ of untreated- or IL-12-treated V $\gamma 9 \mathrm{~V} \delta 2 \mathrm{~T}$ cells expressed BTLA on their surface (Figure 3D); however, treatment
A

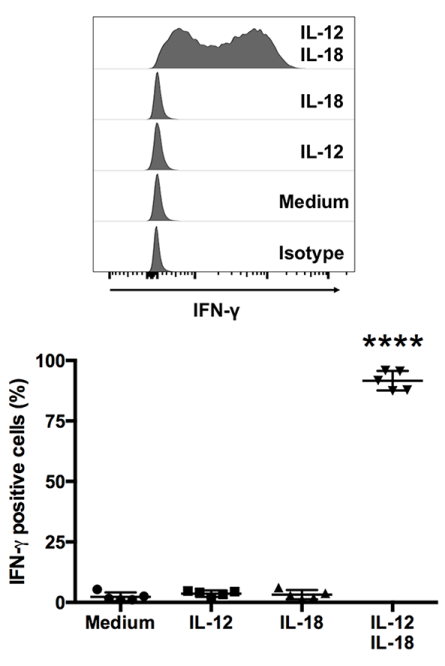

C

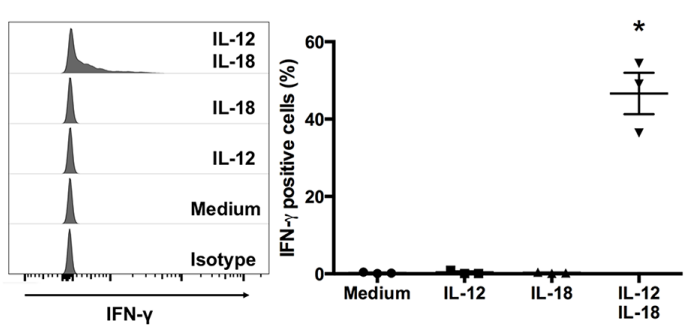

B
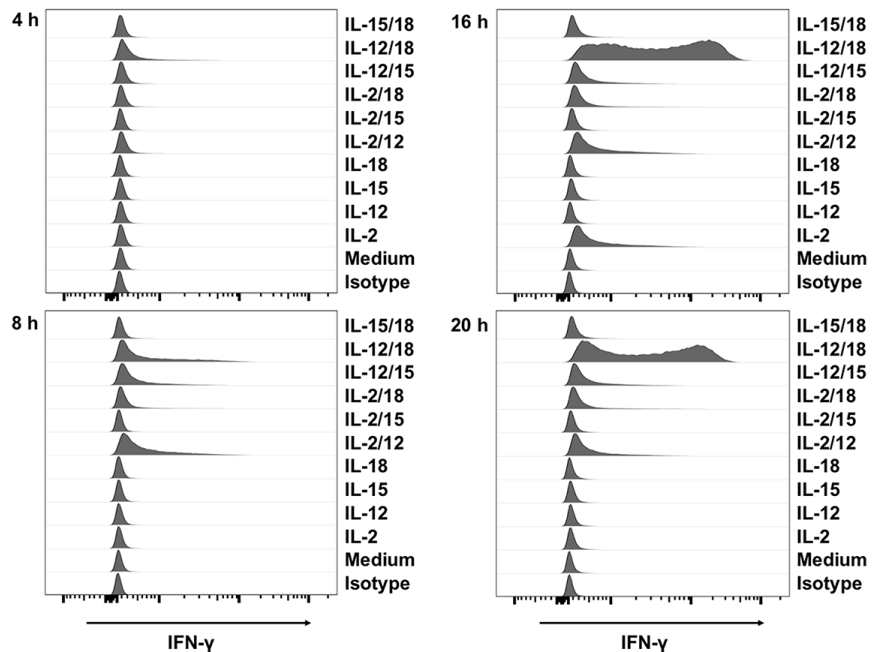

D

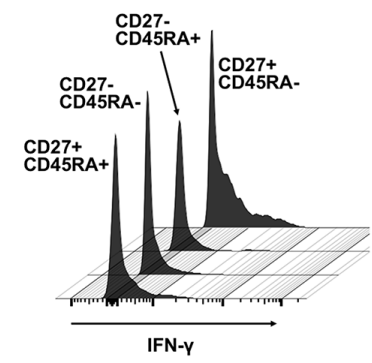

Figure 1: Human $\mathbf{V} \boldsymbol{\gamma} \mathbf{9 V} \boldsymbol{\delta} 2 \mathrm{~T}$ cells produce IFN- $\boldsymbol{\gamma}$ in response to IL-12 and IL-18. (A) Ex vivo-expanded human $\mathrm{V} \gamma 9 \mathrm{~V} \delta 2 \mathrm{~T}$ cells were cultured for $16 \mathrm{~h}$ with medium alone, IL-12 (10 ng/mL), IL-18 (10 ng/mL), or IL-12 and IL-18 (10 ng/mL each). Cells were harvested and analyzed to detect the cell-surface of CD3 and V82 TCR and intracellular expression of IFN- $\gamma$. Data from healthy donors (n $=5$ ) obtained from independent experiments. Bars represent the mean and standard error of the mean (SEM), $* * * * P<0.0001$, one-way ANOVA, followed by Tukey's multiple comparison test. (B) Ex vivo-expanded V $\gamma 9 \mathrm{~V} \delta 2 \mathrm{~T}$ cells were stimulated with indicated cytokines for 4, 8, 16 and $20 \mathrm{~h}$ and the cells were analyzed in the same way as (A). (C) Freshly isolated human $\mathrm{V} \gamma 9 \mathrm{~V} \delta 2 \mathrm{~T}$ cells were stimulated and analyzed in the same way as (A). (D) IL-12/IL-18 treated fleshly isolated V $\gamma 9 \mathrm{~V} \delta 2 \mathrm{~T}$ cells were further analyzed for the differentiation status based on the cell surface expression of CD27 and CD45RA. Data from healthy donors $(n=3)$ obtained from independent experiments. Bars represent the mean and SEM, $* P<0.05$, one-way ANOVA, followed by Tukey's multiple comparison test. 


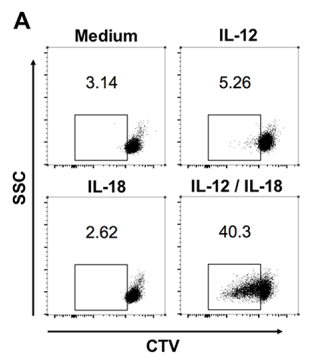

B

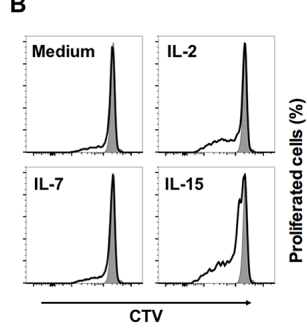

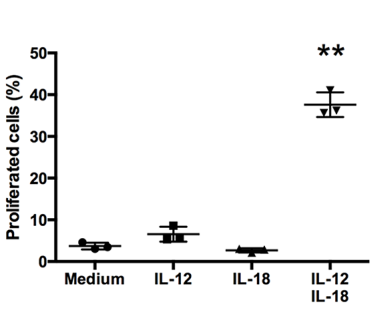

C

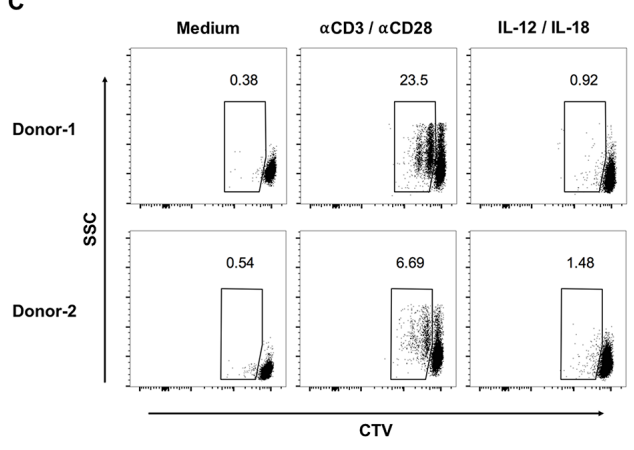

Figure 2: IL-12 and IL-18 synergize to induce the proliferation of ex vivo- expanded human V $\gamma 9 \mathrm{~V} \delta 2$ T cells. (A) CellTrace Violet (CTV)-labeled ex vivo-expanded V $\gamma 9 \mathrm{~V} \delta 2 \mathrm{~T}$ cells were stimulated as described in Figure 1, washed extensively, and cultured in complete medium without cytokines for 3 days. Dot plots were gated on $\mathrm{CD}^{+}{ }^{+} \mathrm{V} \delta 2^{+}$cells and $\mathrm{CTV}^{\text {low }}$ cells were calculated as proliferating cells (left). The data were obtained from 3 independent experiments each using $\mathrm{V} \gamma 9 \mathrm{~V} \delta 2 \mathrm{~T}$ cell from different donors (right). (B) CTV-labeled ex vivo-expanded V $\gamma 9 \mathrm{~V} \delta 2 \mathrm{~T}$ cells were stimulated with IL-12/IL-18 for $16 \mathrm{~h}$, washed extensively, and cultured for 3 days with medium alone, IL-2 $(10 \mathrm{U} / \mathrm{mL})$, IL-7 $(1 \mathrm{ng} / \mathrm{mL})$ or IL-15 $(1 \mathrm{ng} / \mathrm{mL})$. Histograms were gated on $\mathrm{CD}^{+}{ }^{+} \delta 2^{+}$cells and CTV ${ }^{\text {low }}$ cells were calculated as proliferating cells (left). The data were obtained from 4 independent experiments each using $\mathrm{V} \gamma 9 \mathrm{~V} \delta 2 \mathrm{~T}$ cells from different donors (right). Bars represent the mean and SEM, ${ }^{*} P<0.05,{ }^{*} P<0.01$, one-way ANOVA, followed by Tukey's multiple comparison test. (C) CTV-labeled freshly isolated human V $\gamma 9 \mathrm{~V} \delta 2 \mathrm{~T}$ cells were stimulated with IL-12/IL-18 or anti-CD3/anti-CD28 antibodies for 3 days. Dot plots were gated on $\mathrm{CD} 3^{+} \mathrm{V} \delta 2^{+}$cells and $\mathrm{CTV}^{\text {low }}$ cells were calculated as proliferating cells.
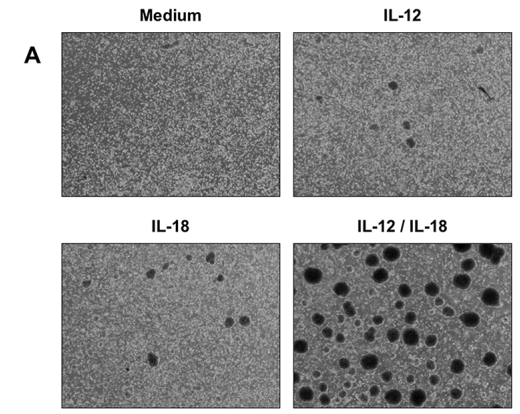

B
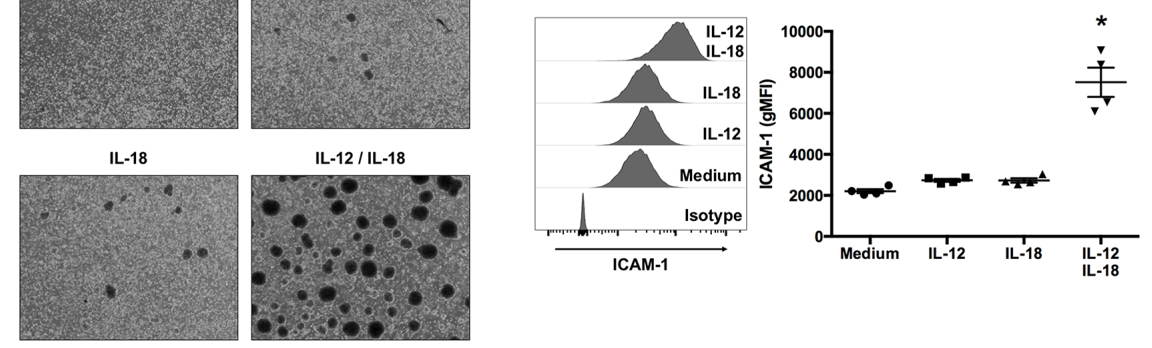

C
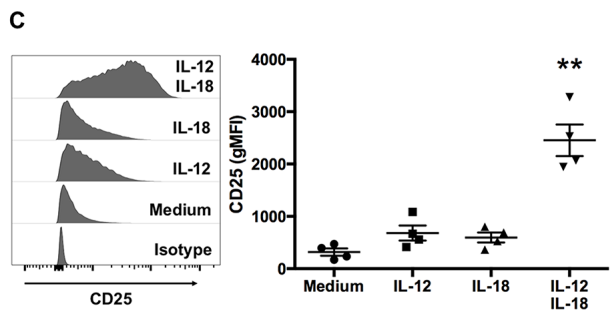

D
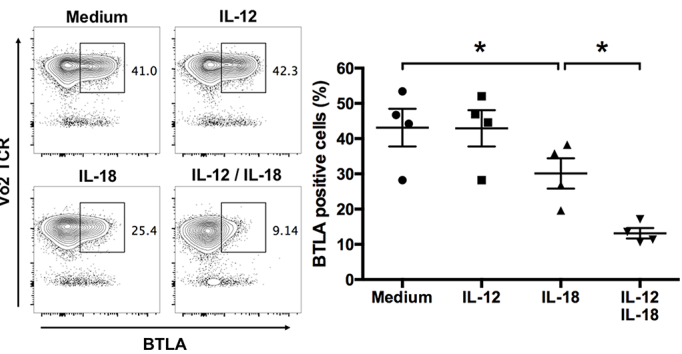

Figure 3: IL-12 and IL-18 treatment of human $\mathrm{V} \gamma 9 \mathrm{~V} \delta 2 \mathrm{~T}$ cells enhances ICAM-1 and CD25 expression, and inhibits BTLA expression. Ex vivo-expanded $\mathrm{V} \gamma 9 \mathrm{~V} \delta 2 \mathrm{~T}$ cells were stimulated as described in Figure 1. (A) Representative images of cytokineactivated V $\gamma 9 \mathrm{~V} \delta 2 \mathrm{~T}$ cells. (B, C) Representative histogram and geometric mean fluorescence intensity (gMFI) of ICAM-1 (B) and CD25 (C) by $\mathrm{CD}^{+} \mathrm{V} \delta 2 \mathrm{TCR}^{+}$cells. (D) Representative contour plots and percentage of BTLA-positive cells gated on CD3 ${ }^{+}$-cells. The data for healthy donors $(\mathrm{n}=4)$ was obtained from independent experiments. Bars represent the mean and SEM, ${ }^{*} P<0.05, * * P<0.01$, one-way ANOVA, followed by Tukey's multiple comparisons test. 
with IL-18 alone and in combination with IL-12 decreased the numbers of BTLA-expressing $\mathrm{V} \gamma 9 \mathrm{~V} \delta 2 \mathrm{~T}$ cells (Figure 3D). Thus, consistent with antigen stimulation, treating $\mathrm{V} \gamma 9 \mathrm{~V} \delta 2 \mathrm{~T}$ cells with IL-12 together with IL-18 inhibited the expression of BTLA.

\section{IL-12 and IL-18 augment $\mathrm{V} \gamma 9 \mathrm{~V} \delta 2 \mathrm{~T}$ cell- mediated cytotoxicity against tumor cells}

V $\gamma 9 \mathrm{~V} \delta 2 \mathrm{~T}$ cells exhibit cytotoxicity against multiple types of tumors [19]. Because $\mathrm{V} \gamma 9 \mathrm{~V} \delta 2 \mathrm{~T}$ cells naturally recognize and kill tumors of B-cell origin [16], we examined the effect of cytokine treatment on the cytotoxic activity of ex vivo-expanded $\mathrm{V} \gamma 9 \mathrm{~V} \delta 2 \mathrm{~T}$ cells against RPMI8226 myeloma cells. Although untreated-V $\gamma 9 \mathrm{~V} \delta 2 \mathrm{~T}$ cells killed $>20 \%$ of RPMI8226 cells, treatment with IL12 alone or in combination with IL-18 strongly enhanced cytotoxic activity (Figure 4A).

For another tumor cell target, we used MG-63 osteosarcoma cells, which are poor activators of $\mathrm{V} \gamma 9 \mathrm{~V} \delta 2$ $\mathrm{T}$ cells in the absence of an anti-CD277 agonistic antibody (20.1) [3]. As expected, untreated ex vivoexpanded V $\gamma 9 \mathrm{~V} \delta 2 \mathrm{~T}$ cells did not kill MG-63 cells efficiently; however, IL-12/IL-18 treatment enhanced their cytotoxicity against MG-63 cells (Figure 4B). These results suggest that combined treatment with IL-12 and IL-18 can enhance the cytotoxicity of ex vivo-expanded $\mathrm{V} \gamma 9 \mathrm{~V} \delta 2 \mathrm{~T}$ cells against tumor cells.

Next, we examined the expression level of granzyme $\mathrm{B}$ in response to these cytokines. Consistent with the enhanced cytotoxic activity, granzyme B expression in ex vivo-expanded $\mathrm{V} \gamma 9 \mathrm{~V} \delta 2 \mathrm{~T}$ cells increased in response to IL-12 and IL-18 (Figure 4C). We next treated IL-12/ IL-18 activated $\mathrm{V} \gamma 9 \mathrm{~V} \delta 2 \mathrm{~T}$ cells with concanamycin A, which attenuates perforin mediated cytotoxicity, before the co-culture with MG-63 cells. As shown in Figure 4D, concanamycin A suppressed the cyototoxic activity of $\mathrm{V} \gamma 9 \mathrm{~V} \delta 2 \mathrm{~T}$ cells against MG-63. Thus, these results suggest that IL-12/IL-18 activated $\mathrm{V} \gamma 9 \mathrm{~V} \delta 2 \mathrm{~T}$ cells kill target tumor cells via secretory granule pathway.

It is reported that the $\mathrm{NK}$ receptor $\mathrm{NKG} 2 \mathrm{D}$ and DNAX Accessory Molecule-1 (DNAM-1) are expressed on $\mathrm{V} \gamma 9 \mathrm{~V} \delta 2 \mathrm{~T}$ cells and contribute to tumor cell recognition [20]. We examined the effect of IL-12 and IL-18 on the cell surface expression level of these receptors and found that NKG2D, but not DNAM-1, increased slightly in response to combined treatment of IL-12 and IL-18 (Figure 4E, 4G). Since MG-63 cells express the ligands to these receptors (Supplementary Figure 2), we utilized blocking antibodies to evaluate the potential role of these receptors in the recognition of MG-63 target cells. Although anti-NKG2D blocking antibody did not affect the cytotoxic activity of $\mathrm{V} \gamma 9 \mathrm{~V} \delta 2 \mathrm{~T}$ cells against MG-63 target cells, blockade of DNAM-1 slightly reduced the cytotoxicity (Figure 4F, 4H). These results suggest that IL12/IL-18 activated $\mathrm{V} \gamma 9 \mathrm{~V} \delta 2 \mathrm{~T}$ cells recognize tumor cells, at least in part, via DNAM-1.

\section{IL-12 and IL-18 synergistically induce IкB $\zeta$ expression in ex vivo-expanded $\mathrm{V} \gamma 9 \mathrm{~V} \delta 2 \mathrm{~T}$ cells}

The transcription factors T-bet and Eomes are critical for IFN- $\gamma$ expression by mouse $\gamma \delta$ T cells $[21,22]$. To determine whether the cytokine-induced production of IFN- $\gamma$ is associated with these transcription factors, we determined the expression levels of T-bet and Eomes in cytokine-treated $\mathrm{V} \gamma 9 \mathrm{~V} \delta 2 \mathrm{~T}$ cells. Most of the ex vivoexpanded $\mathrm{V} \gamma 9 \mathrm{~V} \delta 2 \mathrm{~T}$ cells expressed T-bet and Eomes (Figure 5A, 5B), and the expression levels of T-bet were slightly increased in response to IL-12 treatment (Figure 5A). Recently, two independent groups reported that $\mathrm{I} \kappa \mathrm{B} \zeta$ is indispensable for the induction of IFN- $\gamma$ by NK cells in response to IL-12 and IL-18 [23, 24]. Therefore, we next determined the expression levels of $\mathrm{I} \kappa \mathrm{B} \zeta$ in ex vivo-expanded $\mathrm{V} \gamma 9 \mathrm{~V} \delta 2 \mathrm{~T}$ cells. Although resting, IL12-treated, or IL-18-treated $\mathrm{V} \gamma 9 \mathrm{~V} \delta 2 \mathrm{~T}$ cells did not express $\mathrm{I} \kappa \mathrm{B} \zeta$, combined treatment with IL-12/IL-18 induced $\mathrm{I} \kappa \mathrm{B} \zeta$ expression in $\mathrm{V} \gamma 9 \mathrm{~V} \delta 2 \mathrm{~T}$ cells (Figure $5 \mathrm{C}$ ). To determine whether the ability of cytokines to induce robust expression of $\mathrm{I} \kappa \mathrm{B} \zeta$ in $\mathrm{V} \gamma 9 \mathrm{~V} \delta 2 \mathrm{~T}$ cells is unique to the combination of IL-12 and IL-18, we treated ex vivoexpanded $\mathrm{V} \gamma 9 \mathrm{~V} \delta 2 \mathrm{~T}$ cells with combinations of cytokines including IL-2, IL-12, IL-15 and IL-18. Combined treatment of IL-18 with IL- 2 or IL-15 induced I $\kappa$ B $\zeta$ expression; however, it was not as strong as the combined treatment of IL-12 and IL-18 (Figure 5D).

\section{IкB $\zeta$ expression is critical for the production of IFN- $\gamma$ by ex vivo-expanded $\mathrm{V} \gamma 9 \mathrm{~V} \delta 2 \mathrm{~T}$ cells in response to IL-12 and IL-18}

To determine the significance of I $\kappa \mathrm{B} \zeta$ for the IL-12/ IL-18-induced activation of $\mathrm{V} \gamma 9 \mathrm{~V} \delta 2 \mathrm{~T}$ cells, the cells were transfected with siRNA targeting $\mathrm{I} \kappa \mathrm{B} \zeta$ by electroporation before the treatment of IL-12 and IL-18. We observed that one I $\kappa \mathrm{B} \zeta$-targeting siRNA, s34643, efficiently suppressed the induction of $\mathrm{I} \kappa \mathrm{B} \zeta$ induced by IL-12/IL18 treatment (Figure 6A). We co-stained cell surface and intracellular activation markers with $\mathrm{I} \kappa \mathrm{B} \zeta$. We found that silencing of $\mathrm{I} \kappa \mathrm{B} \zeta$ did not affect the expression levels of BTLA, CD25 and granzyme B (Figure 6B, 6C, 6D), but did result in a slight increase in ICAM-1 expression (Figure 6E). However, silencing of $\mathrm{I} \kappa \mathrm{B} \zeta$ suppressed the robust expression of IFN- $\gamma$ in response to IL-12 and IL18 by $\mathrm{V} \gamma 9 \mathrm{~V} \delta 2 \mathrm{~T}$ cells (Figure 6F). Thus, similar to NK cells, I $\kappa \mathrm{B} \zeta$ induced by IL-12/IL-18 is a critical mediator of IFN- $\gamma$ production by ex vivo-expanded $\mathrm{V} \gamma 9 \mathrm{~V} \delta 2 \mathrm{~T}$ cells.

\section{IL-12 and IL-18 reciprocally increase their cell surface receptor expression in ex vivo-expanded Vy9V82 T cells}

As IL-12 and IL-18 activate the JAK/STAT pathway and the MyD88/TRAF6 pathway, respectively, 
A

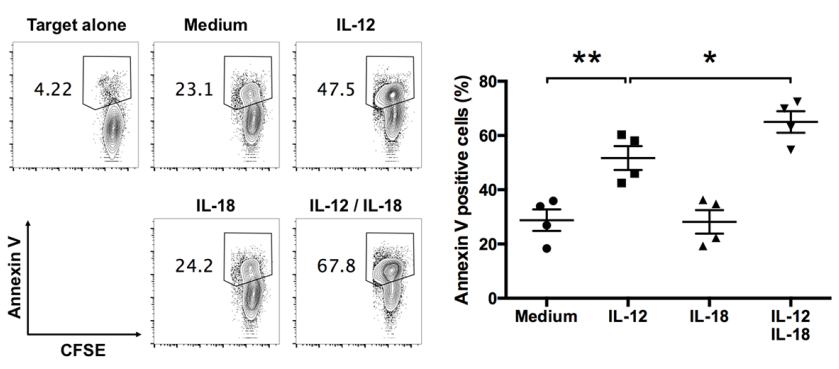

B
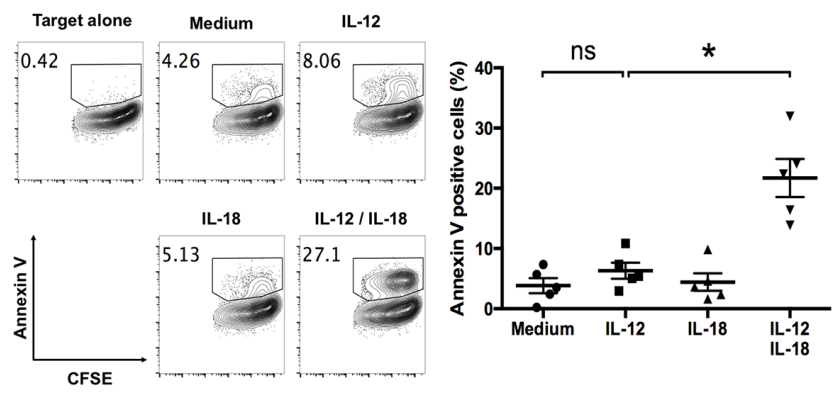

C

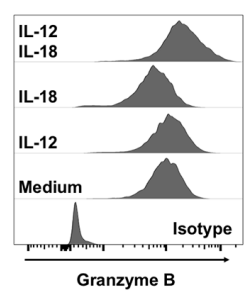

E

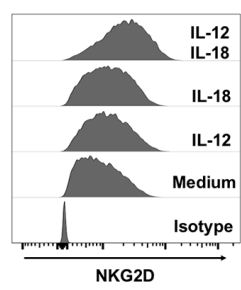

G

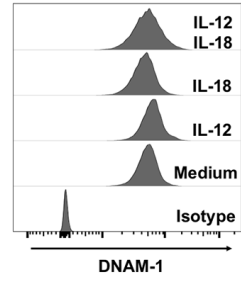

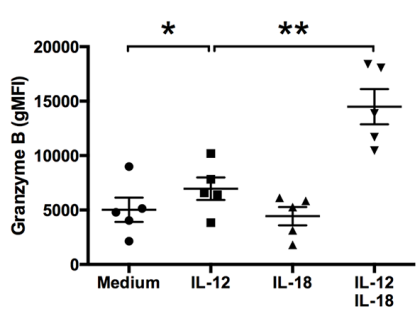
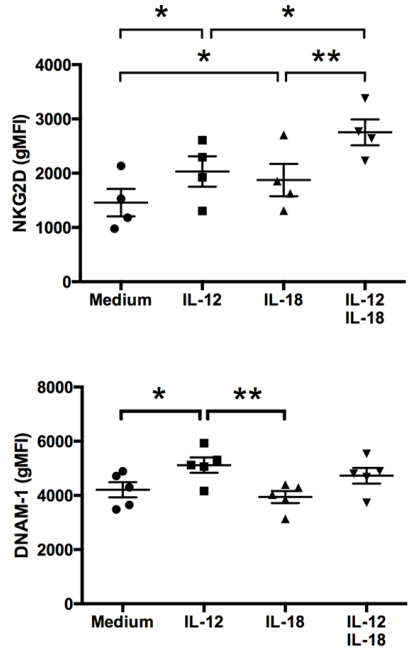

D
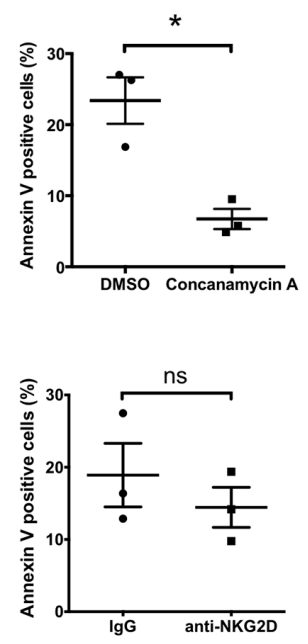

H

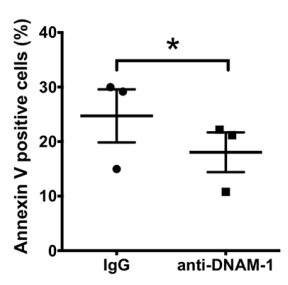

Figure 4: IL-12 alone and in combination with IL-18 augment human V $\gamma 9 \mathrm{~V} \delta 2 \mathrm{~T}$ cell-mediated cytotoxicity. Ex vivoexpanded V $\gamma 9 \mathrm{~V} \delta 2 \mathrm{~T}$ cells were stimulated as described in Figure 1. CFSE-labeled tumor cells were incubated with activated V $\gamma 9 \mathrm{~V} \delta 2 \mathrm{~T}$ cells (A, B). (A) Representative contour plots and percentage of Annexin V-positive RPMI8226 myeloma cells after $2 \mathrm{~h}$ of incubation with cytokine-activated V $\gamma 9 \mathrm{~V} \delta 2 \mathrm{~T}$ cells $(\mathrm{E}: \mathrm{T}=4: 1)$. (B) Representative contour plots and percentage of Annexin V-positive MG-63 osteosarcoma cells after $4 \mathrm{~h}$ of incubation with cytokine-activated V $\gamma 9 \mathrm{~V} \delta 2 \mathrm{~T}$ cells $(\mathrm{E}: \mathrm{T}=8: 1)$. (C, E, G) Representative histogram and gMFI of granzyme B (C), NKG2D (E) and DNAM-1 (G) by $\mathrm{CD}^{+} \mathrm{V} \delta 2 \mathrm{TCR}^{+}$cells. The data were obtained from four (A, E) or five (B, C, G) independent experiments each using V $\gamma 9 \mathrm{~V} \delta 2 \mathrm{~T}$ cells from different donors. Bars represent the mean and SEM, $* P<0.05,{ }^{*} * P<0.01$, one-way ANOVA, followed by Tukey's multiple comparison test. (D, F, H) Ex vivo-expanded V $\gamma 9 \mathrm{~V} \delta 2 \mathrm{~T}$ cells were stimulated with IL-12 and IL-18, then incubated with CFSE-labeled MG63 cells with or without indicated inhibitor (D) or blocking antibodies (F, H). The data were obtained from three independent experiments each using $\mathrm{V} \gamma 9 \mathrm{~V} \delta 2 \mathrm{~T}$ cells from different donors. Bars represent the mean and SEM, $* P<0.05$, two-tailed paired Student $t$ test. 
we investigated whether combined treatment of IL-12 and IL-18 alters these signal transduction pathways in ex vivo-expanded $V \gamma 9 \mathrm{~V} \delta 2 \mathrm{~T}$ cells. First, we examined the activation status of STAT4, which is phosphorylated by JAKs in response to IL-12. Treatment with IL-12 increased phospho-STAT4 (p-STAT4) positive cells (Figure 7A); however, combined treatment with IL18 did not alter the p-STAT4 positive population up to 45-min stimulation (Figure 7A). Next, we examined the proteolytic degradation of $\mathrm{I} \kappa \mathrm{B} \alpha$, a downstream signaling event of the MyD88/TRAF6 pathway, in ex vivo-expanded $\mathrm{V} \gamma 9 \mathrm{~V} \delta 2 \mathrm{~T}$ cells in response to IL-12/ IL-18 treatment. We observed comparable degradation kinetics of I $\kappa \mathrm{B} \alpha$ in IL-18-treated or IL-12/IL-18-treated cells (Figure 7B). Thus, the combined treatment of IL12 and IL-18 did not alter the early proximal signal transduction pathways of each other. It is reported that treatment of $\mathrm{T}$ helper cells with IL-12 or IL-18 enhanced the mRNA transcription of IL-18R $\alpha$ or IL$12 \mathrm{R} \beta 2$, respectively [25]. Therefore, we examined the expression levels of IL-12R $\beta 2$ and IL-18R $\alpha$ on ex vivoexpanded $\mathrm{V} \gamma 9 \mathrm{~V} \delta 2 \mathrm{~T}$ cells after a 16-h stimulation with IL-12 and/or IL-18. Consistent with the previous report, IL-12 and IL-18 increased the cell surface expression of IL-18R $\alpha$ and IL-12R $\beta 2$, respectively (Figure 7C, 7D). Interestingly, we observed that treatment of IL-18 in combination with IL-12 synergistically increased IL$12 \mathrm{R} \beta 2$ expression in $\mathrm{V} \gamma 9 \mathrm{~V} \delta 2 \mathrm{~T}$ cells (Figure 7C).

\section{IL-12 and IL-18 synergistically induce sustained activation of STAT4 and NF-кB in human ex vivo-expanded $\mathrm{V} \gamma 9 \mathrm{~V} \delta 2 \mathrm{~T}$ cells}

Since combined treatment of IL-12 and IL-18 enhanced their cell surface receptor expression, we next examined the activation status of the transcription factors that are activated by IL-12 and IL-18 stimulation. First, to determine if this increased expression of IL-12R $\beta 2$ in response to IL-12/IL-18 exposure affects STAT4 phosphorylation at a later time point, we treated ex vivo-expanded V $\gamma 9 \mathrm{~V} \delta 2 \mathrm{~T}$ cells with IL-12 alone or in combination with IL-18 up to $16 \mathrm{~h}$. We observed that V $\gamma 9 \mathrm{~V} \delta 2 \mathrm{~T}$ cells showed about $40 \%$ of p-STAT4 positive population after 2 -h treatment with IL-12 alone, and the percentage of p-STAT4-positive population declined thereafter (Figure 8A). Although simultaneous treatment of IL-12 and IL-18 resulted in comparable p-STAT4positive $\mathrm{V} \gamma 9 \mathrm{~V} \delta 2 \mathrm{~T}$ cell population at $2 \mathrm{~h}$ post stimulation, the p-STAT4-positive population did not decline thereafter and was sustained at least up to $16 \mathrm{~h}$ post stimulation (Figure 8A). We also examined the recruitment of STAT4 to the IFNG proximal promoter region by chromatin immunoprecipitation (ChIP)-qPCR analysis. We found that STAT4 was recruited to the promoter and $-4 \mathrm{~kb}$ region of IFNG in $\mathrm{V} \gamma 9 \mathrm{~V} \delta 2 \mathrm{~T}$ cells in response to $16 \mathrm{~h}$ stimulation with IL-12 and IL-18 (Figure 8B). Next, we examined whether the increased expression of IL-18R $\alpha$ in response
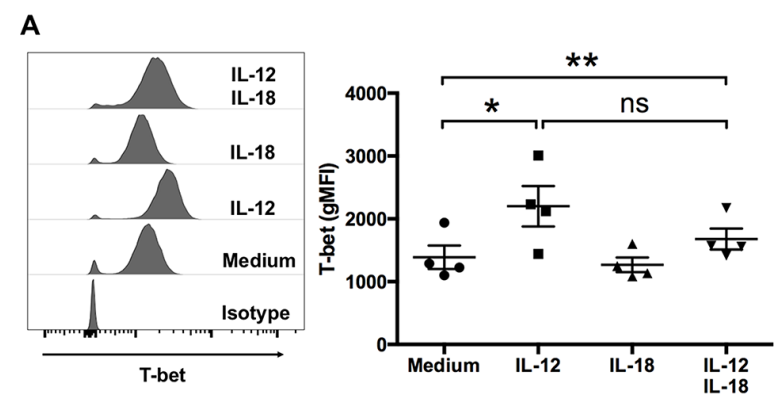

C

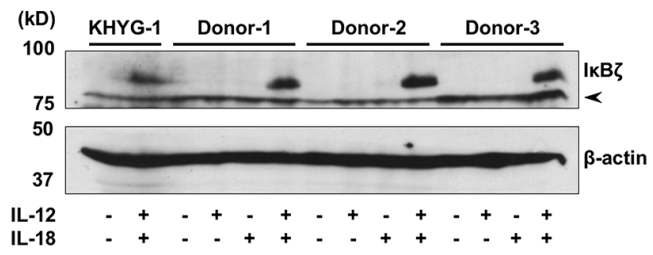

B

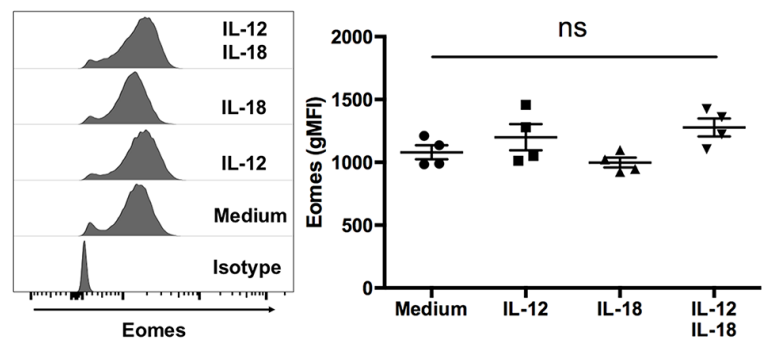

D $\quad(\mathrm{kD})$

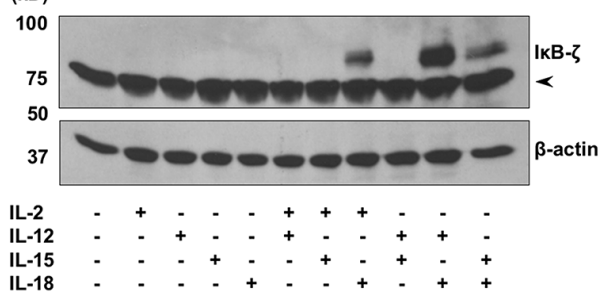

Figure 5: $\mathbf{I} \kappa \mathbf{B} \zeta$ is expressed in human $\mathrm{V} \gamma \mathbf{9 V} \delta 2 \mathrm{~T}$ cells in response to IL-12 and IL-18. Ex vivo-expanded V $\gamma 9 \mathrm{~V} \delta 2 \mathrm{~T}$ cells were stimulated as described in Figure 1. (A, B) Cells were harvested and analyzed to detect the cell-surface of CD3 and V $\delta 2$ TCR and intracellular expression of transcription factors. Representative histogram and gMFI of T-bet (A) and Eomes (B) by $\mathrm{CD}^{+} \mathrm{V} \delta 2 \mathrm{TCR}{ }^{+}$cells. Data from healthy donors $(\mathrm{n}=4)$ obtained from independent experiments. Bars represent the mean and standard error of the mean (SEM),

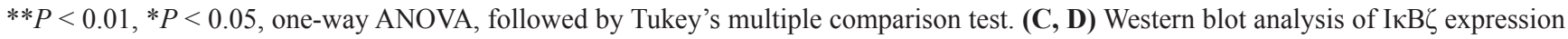
in cell lysates prepared from $\mathrm{V} \gamma 9 \mathrm{~V} \delta 2 \mathrm{~T}$ cells and $\mathrm{KHYG}-1 \mathrm{NK}$ cells which were treated with indicated combinations of cytokines for $16 \mathrm{~h}$. The arrowhead indicates nonspecific band. 
to $16 \mathrm{~h}$ IL-12/IL-18 exposure affects the phosphorylation status of $\mathrm{NF}-\kappa \mathrm{B}$ p 65 at this time point. Untreated and IL-1 8 treated ex vivo-expanded $\mathrm{V} \gamma 9 \mathrm{~V} \delta 2 \mathrm{~T}$ cells showed comparable phosphorylation status of NF- $\kappa \mathrm{B}$ p65. In contrast, IL-12/IL-18 treated cells showed increased phosphorylation status of NF- $\kappa \mathrm{B}$ p65 (Figure $8 \mathrm{C}$ ). These results suggest that increased expression of receptors for IL-12 and IL-18 results in the sustained activation of STAT4 and NF-кB. Finally, we examined whether silencing of $\mathrm{I} \kappa \mathrm{B} \zeta$ affects the enhanced phosphorylation of STAT4 and NF- $\kappa \mathrm{B}$ p 65 in $\mathrm{V} \gamma 9 \mathrm{~V} \delta 2 \mathrm{~T}$ cells in response to IL-12/IL-18. I $\kappa \mathrm{B} \zeta$-silenced $\mathrm{V} \gamma 9 \mathrm{~V} \delta 2 \mathrm{~T}$ cells showed comparable p-STAT4 and p-p65 positive populations compared with that of control cells (Figure 8D, 8E). Thus, the prolonged activation of STAT4 and NF- $\mathrm{BB}$ p65 in $\mathrm{V} \gamma 9 \mathrm{~V} \delta 2 \mathrm{~T}$ cells in response to IL-12/IL-18 is independent of $\mathrm{I} \kappa \mathrm{B} \zeta$ expression.

\section{DISCUSSION}

In addition to NK or T cell receptor activation, $\mathrm{NK}$ cells and $\alpha \beta$ T cells can respond to certain combinations of cytokines, particularly IL-12 and IL-18 [26, 27]. As V $\gamma 9 \mathrm{~V} \delta 2 \mathrm{~T}$ cells respond to IL-12 or IL-18 in combination with antigen stimulation [8], we hypothesized that $\mathrm{V} \gamma 9 \mathrm{~V} \delta 2$ T cells respond to IL-12 and IL-18 independent of NK or $\mathrm{T}$ cell receptor activation. Here, we demonstrated that the combination of IL-12 and IL-18 induces human V $\gamma 9 \mathrm{~V} \delta 2$ $\mathrm{T}$ cell activation independent of the presence of antigen or activation of the NK receptor.

IL-12 and IL-18 synergize to induce IFN- $\gamma$ expression by multiple lymphocyte subsets, including human T cells [28], human $\mathrm{CD}^{+} \mathrm{T}$ cells [29], human $\mathrm{CD}^{+} \mathrm{T}$ cells [30], human NK cells [31], murine NK cells [14], murine $\mathrm{CD}^{+} \mathrm{T}$ cells [32], and murine $\mathrm{CD}^{+}$
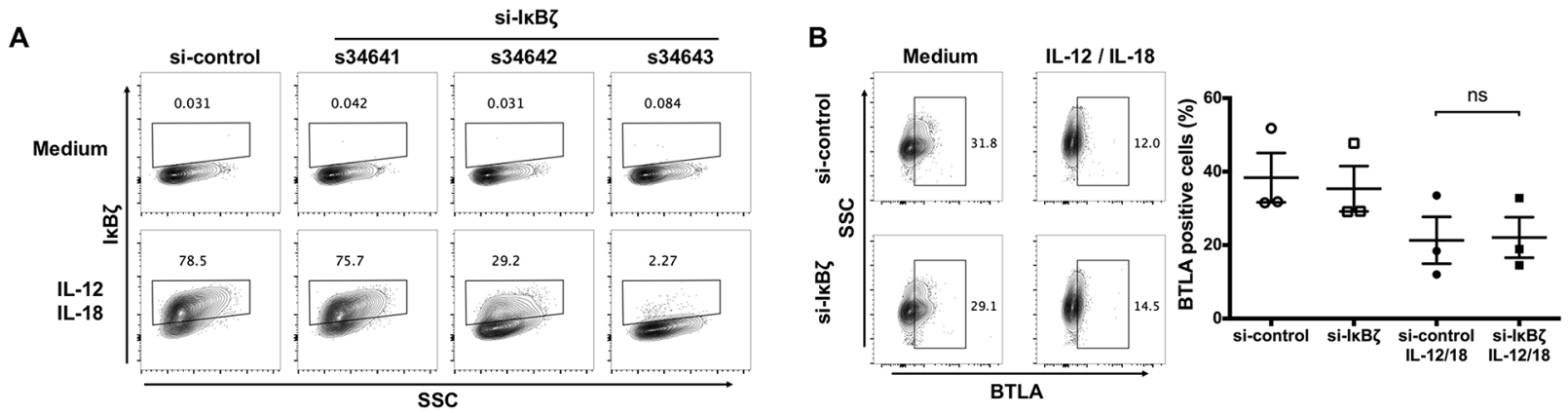

C
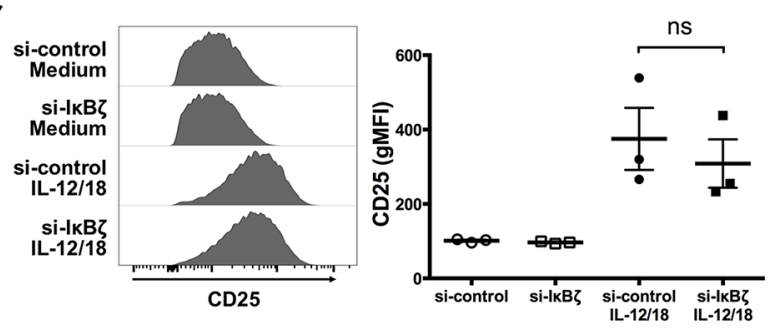

D
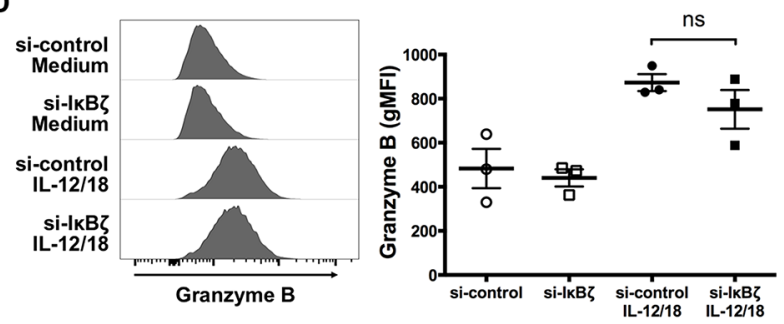

E

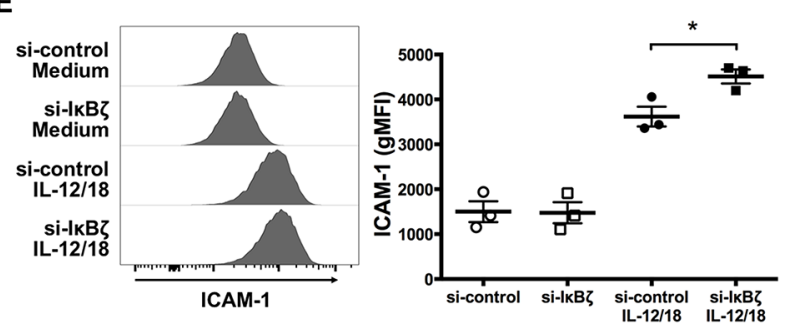

$\mathbf{F}$

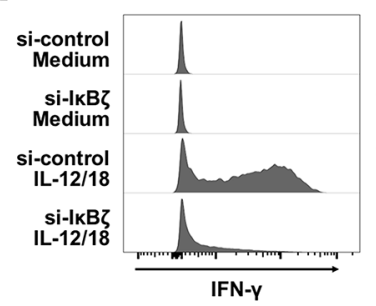

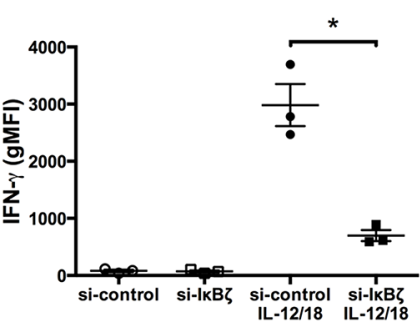

Figure 6: Silencing of IкB $\zeta$ expression in human $V \gamma 9 \mathrm{~V} \delta 2 \mathrm{~T}$ cells attenuates IFN- $\gamma$ production in response to IL-12 and IL-18. Ex vivo-expanded $\mathrm{V} \gamma 9 \mathrm{~V} \delta 2 \mathrm{~T}$ cells were transfected with siRNA targeting I $\kappa \mathrm{B} \zeta$ or control siRNA followed by 16-hour treatment of IL-12 and IL-18. Zombie violet positive cells were gated-out as dead cells. (A) Representative contour plots of I $\kappa$ B $\zeta$-positive cells gated on $\mathrm{CD}^{+} \mathrm{V} \delta 2 \mathrm{TCR}^{+}$cells. Among three different siRNAs targeting I $\kappa \mathrm{B} \zeta$, one (s34643) silenced cytokine-induced I $\mathrm{B} \zeta$ efficiently, and which was used for knocking down I $\kappa \mathrm{B} \zeta$ in further experiments. (B) Representative contour plots and percentage of BTLA-positive cells by $\mathrm{CD}^{+} \mathrm{V} \delta 2 \mathrm{TCR}^{+}$cells. (C-F) Representative histogram (left) and gMFI (right) of CD25 (C), granzyme B (D), ICAM-1 (E) and IFN- $\gamma$ (F) by $\mathrm{CD}^{+} \mathrm{V} \delta 2 \mathrm{TCR}^{+}$cells. The data were obtained from three independent experiments each using $\mathrm{V} \gamma 9 \mathrm{~V} \delta 2 \mathrm{~T}$ cells from different donors. Bars represent the mean and SEM, $* P<0.05$, two-tailed paired Student $t$ test. 
T cells [33]. IFN- $\gamma$ is a Th1 cytokine that is critical for innate and adaptive immune responses, and is produced by $\mathrm{V} \gamma 9 \mathrm{~V} \delta 2 \mathrm{~T}$ cells in response to antigen stimulation [16]. Moreover, our results demonstrated that exposure to IL12 and IL-18 induces robust IFN- $\gamma$ expression by ex-vivo expanded $\mathrm{V} \gamma 9 \mathrm{~V} \delta 2 \mathrm{~T}$ cells. We also demonstrated that IL12 and IL-18 induced IFN- $\gamma$ expression in naïve $\mathrm{V} \gamma 9 \mathrm{~V} \delta 2$ $\mathrm{T}$ cells. These results suggest that activation of $\mathrm{V} \gamma 9 \mathrm{~V} \delta 2$ $\mathrm{T}$ cells by the combination of IL-12 and IL-18 does not require antigen stimulation. This is consistent with the characteristics of $\mathrm{V} \gamma 9 \mathrm{~V} \delta 2 \mathrm{~T}$ cells which are considered as innate-like T lymphocyte with NK cell characteristics [34].

Previous studies of NK and $\alpha \beta$ T cells suggest that in addition to enhanced production of effector molecules and increased cytotoxicity, these cells are induced to proliferate upon exposure to a combination of IL-12 and IL-18 [13, 27]. Our present results demonstrated that ex vivo-expanded $\mathrm{V} \gamma 9 \mathrm{~V} \delta 2 \mathrm{~T}$ cells, but not freshly isolated $\mathrm{V} \gamma 9 \mathrm{~V} \delta 2 \mathrm{~T}$ cells, proliferate in response to combined exposure to IL-12 and IL-18 and that this response is enhanced by subsequent treatment with low concentrations of IL-2 or IL-15.

$\mathrm{V} \gamma 9 \mathrm{~V} \delta 2 \mathrm{~T}$ cells kill a broad range of tumors, including breast cancers [35, 36], colon carcinomas [37], lymphomas [38], melanomas [39], myelomas [16], and prostate cancers [40]. These tumors are particularly

A

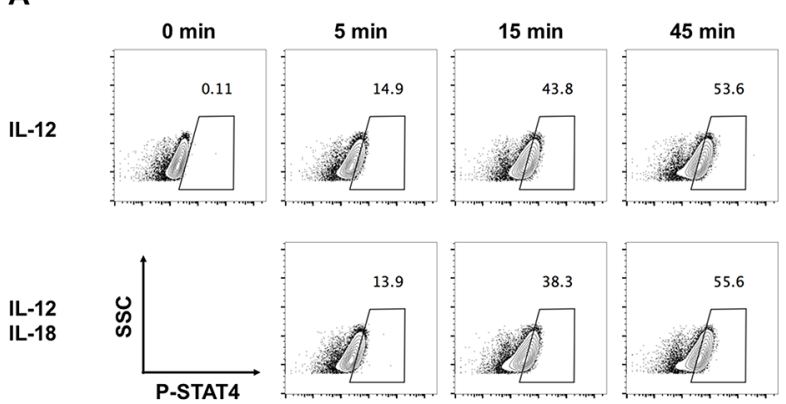

B

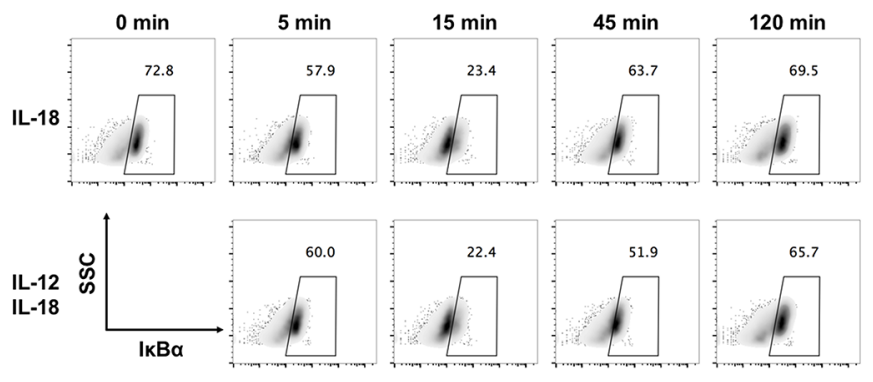

recognized by $\mathrm{V} \gamma 9 \mathrm{~V} \delta 2 \mathrm{~T}$ cells via NK receptors and the V $\gamma 9 \mathrm{~V} \delta 2$ TCR. Using myeloma and osteosarcoma cell lines as targets, we demonstrated here that the treatment of ex vivo-expanded V $\gamma 9 \mathrm{~V} \delta 2$ T cells with IL-12 and IL-18 enhanced their cytotoxic activity against tumor cell lines. We also demonstrated that $\mathrm{V} \gamma 9 \mathrm{~V} \delta 2 \mathrm{~T}$ cells recognize target cells by DNAM-1. Blocking antibodies specific for DNAM-1 significantly blocked $\mathrm{V} \gamma 9 \mathrm{~V} \delta 2 \mathrm{~T}$ cell mediated cytotoxic activity against MG-63 cells. Since the antibody treatment did not completely block the cytotoxic activity, other receptors may contribute to the recognition of tumor cells by IL-12/IL-18 activated V $\gamma 9 \mathrm{~V} \delta 2 \mathrm{~T}$ cells. Thus, using cytokines to regulate the functions of $\mathrm{V} \gamma 9 \mathrm{~V} \delta 2 \mathrm{~T}$ cells might represent an important aspect of applying ex vivo-expanded $\mathrm{V} \gamma 9 \mathrm{~V} \delta 2 \mathrm{~T}$ cells to cancer therapy.

Recent insights into the mechanism underlying IL-12and IL-18-induced IFN- $\gamma$ production by NK cells reveal that the induction of $\mathrm{I} \kappa \mathrm{B} \zeta$ is indispensable for IL-12- and IL-18mediated IFN- $\gamma$ production by human [23] and murine [24] NK cells. Miyake et al. found that IL-12/IL-18 treatment increases $\mathrm{I} \kappa \mathrm{B} \zeta$ mRNA expression by mouse NK cells but not by mouse naïve T cells, Th1 cells, or Th2 cells [24]. Kannan et al. found that treating human lymphocyte with IL$12 / \mathrm{IL}-18$ increased $\mathrm{I} \kappa \mathrm{B} \zeta$ expression by $\mathrm{CD} 56^{+} \mathrm{CD} 14^{-}$cells but not by $\mathrm{CD}^{2} 6^{-} / \mathrm{CD} 14^{-}$cells [23]. These findings suggest that the induction of $\mathrm{I} \kappa \mathrm{B} \zeta$ in response to the combination of IL-12 and IL-18 is unique to NK cells. However, in this

C
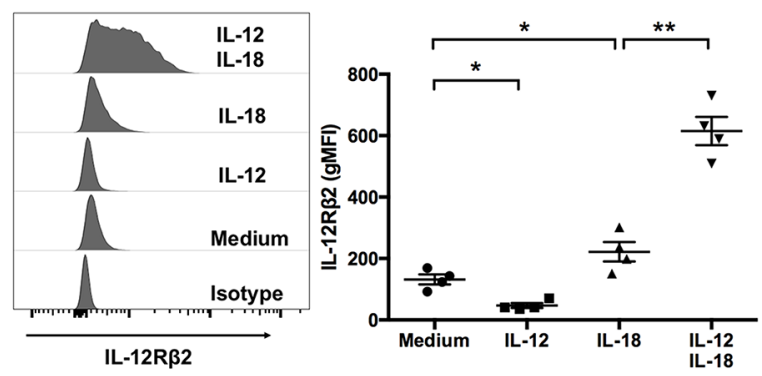

D
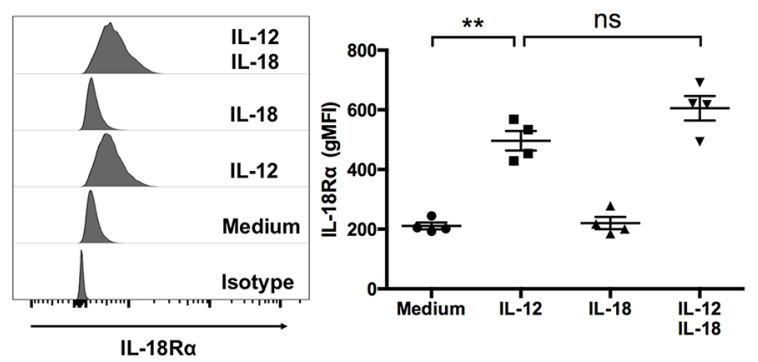

Figure 7: IL-12 increases the expression of IL-18R $\alpha$, and in combination with IL-18, synergistically increase the expression of IL-12Rß2 in human $V \gamma \gamma \mathbf{V} \delta 2$ T cells. (A, B) Ex vivo-expanded $V \gamma 9 \mathrm{~V} \delta 2 \mathrm{~T}$ cells were stimulated with indicated cytokines for different periods of time. Representative contour plots of p-STAT4-positive cells (A) and representative density plots of I $\mathrm{B} \alpha$-positive cells (B). (C, D) Ex vivo-expanded $\mathrm{V} \gamma 9 \mathrm{~V} \delta 2 \mathrm{~T}$ cells were stimulated as described in Figure 1. Representative histogram and gMFI of IL-12R $\beta 2$ (C) and IL-18R $\alpha$ (D) by $\mathrm{CD}^{+} \mathrm{V} \delta 2 \mathrm{TCR}^{+}$cells. The data for healthy donors $(\mathrm{n}=4)$ was obtained from independent experiments. Bars represent the mean and SEM, ${ }^{*} P<0.05$, ${ }^{*} P P<0.01$, one-way ANOVA, followed by Tukey's multiple comparisons test. 

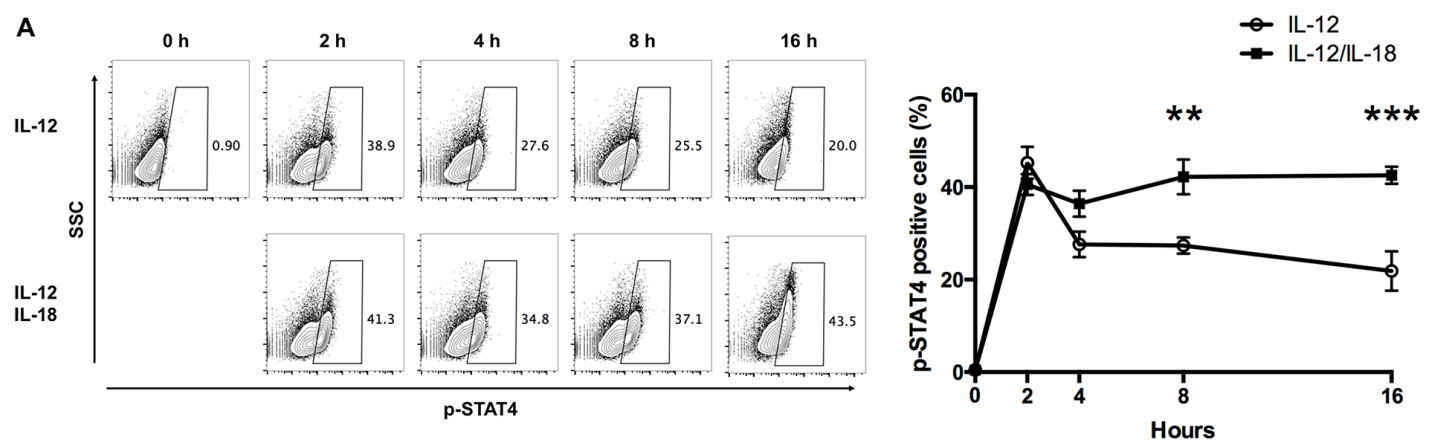

B
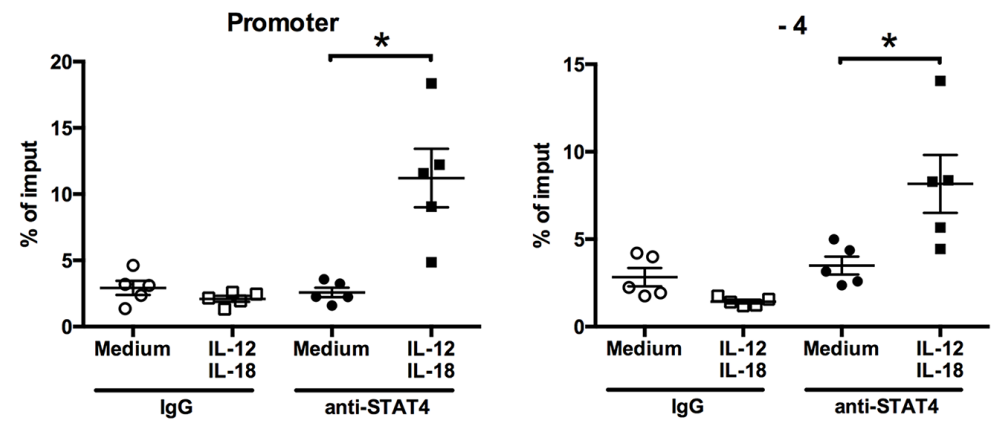

C

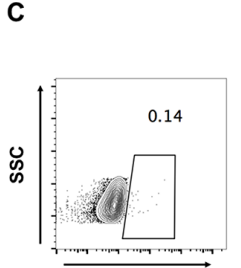

Isotype

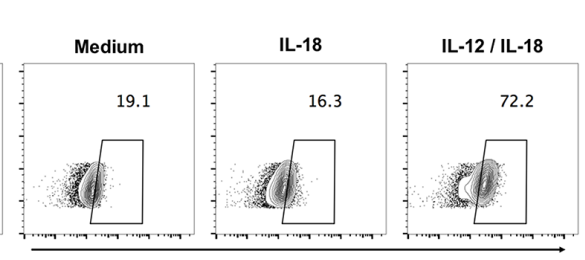

p-p65
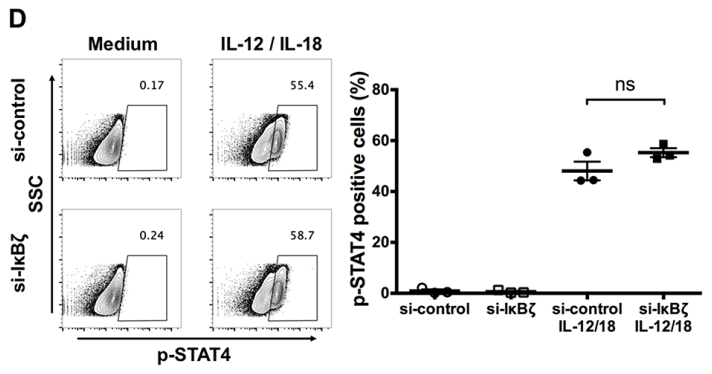

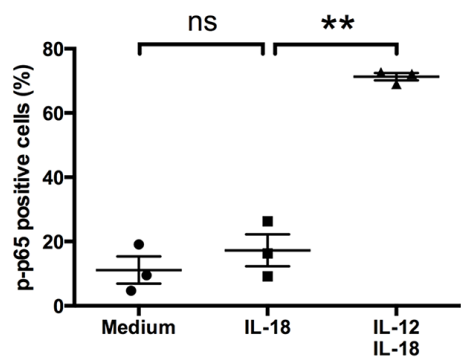

E
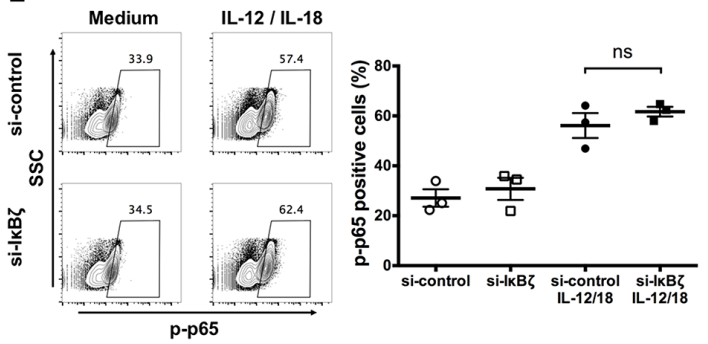

Figure 8: IL-12 and IL-18 synergistically induce sustained phosphorylation of STAT4 and NF- $\kappa B$ p 65 in human V $\gamma 9 \mathrm{~V} \delta 2$ T cells. (A) Ex vivo-expanded V $\gamma 9 \mathrm{~V} 82 \mathrm{~T}$ cells were stimulated with IL-12 alone or in combination with IL-18 for different periods. Representative contour plots and percentage of p-STAT4 positive cells. The data for healthy donors $(n=4)$ was obtained from independent experiments. Bars represent the mean and SEM, ${ }^{* *} P<0.01,{ }^{* * *} P<0.001$, two-way ANOVA, followed by Sidak's multiple comparisons test. (B) Ex vivo-expanded V $\gamma 9$ V $82 \mathrm{~T}$ cells were activated with IL-12 and IL-18 for $16 \mathrm{~h}$ followed by chromatin immunoprecipitation using anti-STAT4 Ab. Recruitment of STAT4 to the promoter (left) and $-4 \mathrm{~kb}$ (right) of IFN- $\gamma$ gene regions were analyzed by qPCR. The data were obtained from five independent experiments each using $\mathrm{V} \gamma 9 \mathrm{~V} \delta 2 \mathrm{~T}$ cells from different donors. Bars represent the mean and SEM, *P $<0.05$, two-tailed paired Student $t$ test. (C) Ex vivo-expanded V $\gamma 9 \mathrm{~V} \delta 2 \mathrm{~T}$ cells were stimulated with IL-18 alone or in combination with IL-12 for $16 \mathrm{~h}$. Representative contour plots and percentage of p-p65 positive cells. The data for healthy donors $(\mathrm{n}=3)$ was obtained from independent experiments. Bars represent the mean and SEM, $* * P<0.01$, one-way ANOVA, followed by Tukey's multiple comparison test. (D, E) Ex vivo-expanded $\mathrm{V} \gamma 9 \mathrm{~V} \delta 2 \mathrm{~T}$ cells were transfected with siRNA targeting I $\mathrm{KB} \zeta$ or control siRNA followed by 16-hour treatment of IL-12 and IL-18. Representative contour plots and percentage of p-STAT4- (D) and p-p65- (E) positive cells by $\mathrm{CD}^{+} \mathrm{V}^{-} 2 \mathrm{TCR}^{+}$cells. The data were obtained from three independent experiments each using $\mathrm{V} \gamma 9 \mathrm{~V} \delta 2 \mathrm{~T}$ cells from different donors. Bars represent the mean and SEM, two-tailed paired Student $t$ test. 
study, we demonstrated that ex vivo-expanded $\mathrm{V} \gamma 9 \mathrm{~V} \delta 2 \mathrm{~T}$ cells induce I $\mathrm{KB} \zeta$ expression in response to IL-12/IL-18 as well, and silencing of $\mathrm{I} \kappa \mathrm{B} \zeta$ attenuates the robust induction of IFN- $\gamma$. In contrast to the critical role for the regulation of IFN- $\gamma$, silencing of I $\kappa$ B $\zeta$ did not affect the expression levels of granzyme B, CD25, and BTLA in IL-12/IL-18-treated V $\gamma 9$ V 82 T cells. Therefore, we explored other mechanisms underlining the cytokine-mediated activation of ex vivoexpanded $\mathrm{V} \gamma 9 \mathrm{~V} \delta 2 \mathrm{~T}$ cells. We showed that $\mathrm{V} \gamma 9 \mathrm{~V} \delta 2 \mathrm{~T}$ cells treated with IL-12 or IL-18 enhanced the surface expression of IL-18R $\alpha$ and IL-12R $\beta 2$, respectively, and this is consistent with the previous report that IL-12 or IL-18 reciprocally induced their receptors in Th cells [25]. Moreover, our results showed that IL-12 and IL-18 synergistically increased IL$12 \mathrm{R} \beta 2$ expression in $\mathrm{V} \gamma 9 \mathrm{~V} \delta 2 \mathrm{~T}$ cells compared with that by IL-18 treatment alone. We propose that this increased cell surface expression of IL-12R $\beta 2$ and IL-18R $\alpha$ may result in more efficient cytokine signaling. To test this hypothesis, we examined the phosphorylation status of STAT4 and NF- $\mathrm{BB}$ p65 in ex vivo-expanded V $\gamma 9 \mathrm{~V} \delta 2 \mathrm{~T}$ cells treated with IL12 and/or IL-18. Our results demonstrated that although both IL-12 alone or IL-12/IL-18 treatment resulted in comparable activation of STAT4 in V $\gamma 9 \mathrm{~V} \delta 2 \mathrm{~T}$ cells, the duration of activation of STAT4 was longer in IL-12/IL-18-treated cells than in cells treated with IL-12 alone. Further, p-p65 NF- $\kappa$ B positive populations in IL-12/IL-18-treated cells are higher than that of IL-18 alone-treated cells. These results might reflect the enhanced surface expression of IL-12R $\beta 2$ and IL$18 \mathrm{R} \alpha$ on IL-12/IL-18 treated cells. These results suggest that IL-12 and IL-18 treatment synergistically activate ex vivoexpanded $\mathrm{V} \gamma 9 \mathrm{~V} \delta 2 \mathrm{~T}$ cells through the induction of $\mathrm{I} \kappa \mathrm{B} \zeta$, and increased expression of IL-12R $\beta 2$ and IL-18R $\alpha$, resulting in sustained activation of STAT4 and NF- $\mathrm{KB}$.

In conclusion, we demonstrate that the combined treatment of IL-12 and IL-18 regulates multiple effector functions of $\mathrm{V} \gamma 9 \mathrm{~V} \delta 2 \mathrm{~T}$ cells, and the induction of $\mathrm{I} \kappa \mathrm{B} \zeta$ and prolonged activation of STAT4 and NF- $\kappa \mathrm{B}$ are key regulators of the cytokine activation of ex vivo-expanded $\mathrm{V} \gamma 9 \mathrm{~V} \delta 2 \mathrm{~T}$ cells. Thus, our data reveal a novel technique and molecular basis for regulating the phenotype of ex vivoexpanded $\mathrm{V} \gamma 9 \mathrm{~V} \delta 2 \mathrm{~T}$ cells that can be clinically exploited for enhancing the efficacy of tumor immunotherapy.

\section{MATERIALS AND METHODS}

\section{Ethics}

Peripheral blood from healthy volunteers was obtained after obtaining written informed consent from them with the approval of the Research Ethics Committee of Osaka Dental University.

\section{Preparation of ex vivo-expanded $\mathrm{V} \gamma 9 \mathrm{~V} \delta 2 \mathrm{~T}$ cells}

Peripheral blood mononuclear cells (PBMCs) were isolated from fresh blood by density gradient centrifugation using a BD Vacutainer CPT (BD Biosciences, San Jose, CA). PBMCs were cultured at $37^{\circ} \mathrm{C}$ and $5 \% \mathrm{CO}_{2}$ in 24-well plate at a density of $1 \times 10^{6}$ cells $/ \mathrm{mL}$ in RPMI 1640 (Wako, Japan) that was supplemented with $10 \%$ FBS (Sigma-Aldrich, St. Louis, MO), 4 mM L-glutamine, $100 \mathrm{U} / \mathrm{mL}$ penicillin, $100 \mu \mathrm{g} / \mathrm{mL}$ streptomycin (Nacalai tesque, Japan), $100 \mathrm{U} / \mathrm{mL}$ IL-2 (Primmune, Japan), and 5 $\mu \mathrm{M}$ zoledronic acid (Cayman Chemical, Ann Arbor, MI). To expand V $\gamma 9 \mathrm{~V} \delta 2 \mathrm{~T}$ cells, additional IL-2 (100 U/mL) was added on day 3 to prevent IL-2 starvation, and the culture density was maintained at 0.5 to $2 \times 10^{6}$ cells $/ \mathrm{mL}$ by adding fresh medium supplemented with IL-2 (100 U/ $\mathrm{mL}$ ). On day 14, the expanded cells were collected and extensively washed with medium; thereafter, they were cryopreserved for further experiments. The purity of Vy9V $\delta 2$ T cells was $>93 \%$.

\section{Isolation of $\mathrm{V} \gamma 9 \mathrm{~V} \delta 2 \mathrm{~T}$ cells from fleshly prepared PBMC}

Untouched $\mathrm{V} \gamma 9 \mathrm{~V} \delta 2 \mathrm{~T}$ cells were enriched from fleshly isolated PBMC using $\gamma / \delta^{+} \mathrm{T}$ cell isolation kit, human (Miltenyi Biotec, Auburn, CA) according to the manufacture's protocol. The purity of $\mathrm{V} \gamma 9 \mathrm{~V} \delta 2 \mathrm{~T}$ cells was $>85 \%$.

\section{Cell culture}

The KHYG-1 NK cell line was provided by H. Umehara [41]. RPMI8226 myeloma and MG-63 osteosarcoma cell lines were obtained from the RIKEN BioResource Center (Tsukuba, Japan) and cultured in RPMI-1640 or DMEM, each of which were supplemented with $10 \% \mathrm{FBS}, 4 \mathrm{mM}$ L-glutamine, $100 \mathrm{U} / \mathrm{mL}$ penicillin, and $100 \mu \mathrm{g} / \mathrm{mL}$ streptomycin. For cytokine-mediated activation of $\mathrm{V} \gamma 9 \mathrm{~V} \delta 2 \mathrm{~T}$ cells, cryopreserved cells were thawed and extensively washed with medium; thereafter, they were cultured for indicated period with IL-2 (100 U/mL), IL-12 (10 ng/mL) (BioLegend, San Diego, CA), IL-15 (10 ng/mL) (BioLegend), IL-18 (10 ng/mL) (MBL International, Woburn, MA), or two out of them.

\section{Flow cytometry (FACS)}

Cells were labeled with the monoclonal antibodies as follows: CD3 (clone OKT3) and ICAM-1 (clone 15.2) from Tonbo Biosciences (San Diego, CA); TCR V82 (clone B6), TCR V $\gamma 9$ (clone B3), CD25 (clone BC96), CD27 (clone O323), CD45RA (HI100), BTLA (clone MIH26), NKG2D (clone 1D11), DNAM-1 (clone $11 \mathrm{~A} 8$ ), and IL-18R $\alpha$ (clone H44) from BioLegend; IL12Rß2 (REA333) from Miltenyi Biotec. For detecting transcription factor expression, cells were surface-stained, fixed, permeabilized using the Foxp3/Transcription Factor Staining Buffer Set (eBioScience, San Diego, CA), and stained with anti-T-bet (clone REA102) (Miltenyi Biotec), 
anti-Eomes (clone WD1928) (eBioscience) and anti-IкB $\zeta$ (clone hft2nap) (eBioscience) antibodies. For intracellular staining, monensin (BioLegend) was added during the last $2 \mathrm{~h}$ of culture. After staining with antibodies to detect cell surface antigens, cells were fixed and permeabilized using Fixation and Perm/Wash buffer (BioLegend) and then treated with anti-IFN- $\gamma$ (clone 4S. B3) and granzyme B (clone GB11) antibodies (both from BioLegend). For examining kinetics of signal transduction molecules, cytokine treated cells were fixed immediately by adding IC Fixation buffer (eBioscience) followed by particular permeabilization methods. For detecting intracellular $\mathrm{I} \kappa \mathrm{B} \alpha$, fixed cells were permabilized with Perm/Wash buffer (BioLegend) followed by incubation with anti$\mathrm{I} \kappa \mathrm{B} \alpha$ antibody (clone MFRDTRK) (eBioscience). For detecting intracellular p-STAT4 or p-p65, fixed cells were permabilized with ice cold methanol followed by incubation with anti-p-STAT4 (Y693) antibody (clone 4LURPIE) (eBioscience) or anti-p-NF- $\kappa$ B p65 (S536) antibody (clone 93H1) (Cell Signaling Technology, Danvers, MA). Data were collected using a BD FACSVerse (BD); the resulting data were analyzed using FlowJo software X 10.0.7 (Tree Star, Ashland, OR).

\section{Cell proliferation assay}

V $\gamma 9 \mathrm{~V} \delta 2 \mathrm{~T}$ cells were labeled with $2 \mu \mathrm{M}$ CTV (Life Technologies, Grand Island, NY) and treated with IL-12, IL-18, or both for $16 \mathrm{~h}$. After extensive washing, $\mathrm{V} \gamma 9 \mathrm{~V} \delta 2$ $\mathrm{T}$ cells were further cultured with medium alone or with medium supplemented with IL-2, IL-7 (BioLegend), or IL-15 for an additional 3 days. $\mathrm{CD}^{+} \mathrm{V} \delta 2 \mathrm{TCR}^{+}$cells were gated, and CTV-diluted cells were counted as dividing cells. In some experiments, labeled $\mathrm{V} \gamma 9 \mathrm{~V} \delta 2 \mathrm{~T}$ cells were stimulated with plate bound anti-CD3 (clone UCHT1) and soluble anti-CD28 (clone CD28.2) (both from BioLegend) and used for positive control.

\section{In vitro tumor killing assay}

Ex vivo-expanded $\mathrm{V} \gamma 9 \mathrm{~V} \delta 2 \mathrm{~T}$ cells were activated as described above and extensively washed with medium to remove cytokines. RPMI8226 myeloma cells were labeled with $1 \mu \mathrm{M}$ carboxyfluorescein succinimidyl ester (CFSE) (Dojindo), and $1 \times 10^{5}$ CFSE-labeled tumor cells were incubated with $4 \times 10^{5} \mathrm{~V} \gamma 9 \mathrm{~V} \delta 2 \mathrm{~T}$ cells in RPMI1640 for $2 \mathrm{~h}$ in a 24-well plate. MG-63 osteosarcoma cells were cultured overnight at a density of $6 \times 10^{4}$ cells per well in a 48 -well plate and then labeled with $1 \mu \mathrm{M}$ CFSE before incubation with $4.8 \times 10^{5} \mathrm{~V} \gamma 9 \mathrm{~V} \delta 2 \mathrm{~T}$ cells in RPMI-1640 for $4 \mathrm{~h}$. Cells were collected and stained with Annexin V-APC (BioLegend) and subjected to FACS analysis. $\mathrm{CFSE}^{+}$Annexin $\mathrm{V}^{+}$cells were considered to be dead tumor cells. In some experiments, IL-12/IL-18 activated $\mathrm{V} \gamma 9 \mathrm{~V} \delta 2 \mathrm{~T}$ cells were treated with $100 \mathrm{ng} / \mathrm{mL}$ of concanamycin A (Santa Cruz Biotechnology, Dallas,
TX), $10 \mu \mathrm{g} / \mathrm{mL}$ of anti-NKG2D (clone 1D11) (BioLegend) or $10 \mu \mathrm{g} / \mathrm{mL}$ of anti-DNAM-1 (clone 102511) (R\&D Systems, Minneapolis, MN) for $30 \mathrm{~min}$ before the coincubation with MG-63 cells.

\section{Western blotting}

Ex vivo-expanded $\mathrm{V} \gamma 9 \mathrm{~V} \delta 2 \mathrm{~T}$ cells were activated as described above and lysed directly in sample buffer. Samples were sonicated and boiled for $3 \mathrm{~min}$ and then separated using $8 \%$ SDS-PAGE with $6 \times 10^{5}$ cell equivalents loaded per lane. The proteins were transferred to PVDF membranes, which were blocked with TBS containing 5\% BSA and $0.1 \%$ Tween 20, and probed with rabbit anti-human I $\kappa$ B $\zeta$ (\#9244) (Cell Signaling Technology) or mouse anti- $\beta$ actin (clone AC-74) (Sigma-Aldrich, St. Louis, MO) antibodies, followed by incubation with HRP-conjugated secondary antibodies (GE Health Care Life sciences, U.K.). The chemiluminescence signal was generated using SuperSignal West Pico Chemiluminescent Substrate (GE Health Care Life sciences) and detected using Amersham Hyperfilm ECL (GE Health Care Life sciences).

\section{siRNA transfection}

Transfection of siRNA was conducted using Amaxa Nucleofector device and human T cell nucleofector kit (Lonza, Basel,Switzerland) according to the manufacture's protocol. Briefly, cryopreserved ex vivo-expanded $\mathrm{V} \gamma 9 \mathrm{~V} \delta 2 \mathrm{~T}$ cells were thawed and incubated in complete medium for $2 \mathrm{~h} ; 5 \times 10^{6} \mathrm{~V} \gamma 9 \mathrm{~V} \delta 2 \mathrm{~T}$ cells were transfected with $300 \mathrm{nM}$ of negative control or $\mathrm{I} \kappa \mathrm{B} \zeta$ targeting (s34641, s34642, or s34643) siRNAs (silencer select, Thermo Fisher scientific, Rockford, IL) with device's program T-20. Transfected cells were cultured in complete medium for $4 \mathrm{~h}$ then used for further experiments.

\section{Chromatin immunoprecipitation (ChIP)}

Ex vivo-expanded $\mathrm{V} \gamma 9 \mathrm{~V} \delta 2 \mathrm{~T}$ cells that were stimulated with IL-12/IL-18 for $16 \mathrm{~h}$ were cross-linked with $1 \%$ formaldehyde for $10 \mathrm{~min}$ at room temperature, followed by incubation with $125 \mathrm{mM}$ glycine. Cells were harvested, washed with PBS and re-suspended in $0.5 \mathrm{~mL}$ of ChIP buffer (10 mM HEPES-KOH (pH 7.9), 200 mM $\mathrm{KCl}, 1 \mathrm{mM} \mathrm{CaCl}, 1.5 \mathrm{mM} \mathrm{MgCl}, 5 \%$ sucrose and $0.5 \%$ NP-40) containing $10 \mu \mathrm{M}$ N-(Methoxysuccinyl)-Ala-AlaPro-Val-chloromethyl-ketone (Sigma-Aldrich), $1 \mathrm{mM}$ sodium orthovanadate (New England Biolabs, Ipswich, MA) and protease inhibitor cocktail (Nacalai tesque). The lysates were incubated on ice for $15 \mathrm{~min}$ and sonicated for $5 \mathrm{~s}$ three times, followed by digestion with $2 \mu \mathrm{L}$ of Micrococcal Nuclease (New England Biolabs) and $2 \mu \mathrm{L}$ of $10 \mathrm{mg} / \mathrm{mL}$ RNase A (Thermo Fisher scientific) for $40 \mathrm{~min}$ 
at $37^{\circ} \mathrm{C}$. After adding $5 \mu \mathrm{L}$ of $0.5 \mathrm{M}$ EDTA, the digested samples were centrifuged at $20,000 \times g$ for $10 \mathrm{~min}$. The supernatants were incubated with anti-STAT4 antibody (clone EP1900Y, Abcam, Cambridge, MA) / dynabeads protein $\mathrm{G}$ (Thermo Fisher scientific) complexes at $4{ }^{\circ} \mathrm{C}$ overnight. The immunoprecipitated complexes were washed twice with ChIP buffer and twice with TE buffer. After that, cross-links were reversed by incubating in ChIP direct elution buffer (10 mM Tris- $\mathrm{HCl}$ (pH 8.0), 300 $\mathrm{mM} \mathrm{NaCl}, 5 \mathrm{mM}$ EDTA and $0.5 \% \mathrm{SDS}$ ) for $6 \mathrm{~h}$ at $65^{\circ} \mathrm{C}$. After incubation with $50 \mu \mathrm{g} / \mathrm{mL}$ of proteinase $\mathrm{K}$ (Thermo Fisher scientific) for $1 \mathrm{~h}$ at $55^{\circ} \mathrm{C}$, DNA was purified by phenol-chloroform extraction and ethanol precipitation using Dr. GenTLE Precipitation Carrier (TaKaRa, Japan). Quantitative real-time PCR was performed by Thunderbird SYBR qPCR Mix (Toyobo, Japan) and the products were detected with StepOnePlus Real-Time PCR System (Thermo Fisher scientific). The primers were purchased from Cell Signaling Technology (SimpleChIP Human IFN- $\gamma$ promoter primers \#13051) and QIAGEN (EpiTect ChIP qPCR Assay GPH1017290 (-4kb)). Each ChIP value was normalized by the input.

\section{Statistical analysis}

Statistical analysis was performed using GraphPad Prism software 6.0 for Mac OS X (GraphPad Software, La Jolla, CA). Two-tailed Student $t$ test or One-way ANOVA followed by Tukey's or Dunnett's multiple comparison tests were used to assess the statistical significance of the differences between data.

\section{CONFLICTS OF INTEREST}

The authors declare no commercial or financial conflicts of interest.

\section{FUNDING}

This work was supported by JSPS KAKENHI Grant Numbers JP26861583 (E.Domae), JP26870286 (Y.Hirai).

\section{REFERENCES}

1. Kabelitz D, Kalyan S, Oberg HH, Wesch D. Human $\mathrm{V} \delta 2$ versus non-V $\delta 2 \gamma \delta \mathrm{T}$ cells in antitumor immunity. Oncoimmunology. 2013; 2:e23304.

2. Sandstrom A, Peigne CM, Leger A, Crooks JE, Konczak F, Gesnel MC, Breathnach R, Bonneville M, Scotet E, Adams EJ. The intracellular B30.2 domain of butyrophilin $3 \mathrm{~A} 1$ binds phosphoantigens to mediate activation of human Vy9V82 T cells. Immunity. 2014; 40:490-500.

3. Harly C, Guillaume Y, Nedellec S, Peigne CM, Monkkonen H, Monkkonen J, Li J, Kuball J, Adams EJ, Netzer S, Dechanet-Merville J, Leger A, Herrmann T, et al. Key implication of CD277/butyrophilin-3 (BTN3A) in cellular stress sensing by a major human gammadelta T-cell subset. Blood. 2012; 120:2269-2279.

4. Vavassori S, Kumar A, Wan GS, Ramanjaneyulu GS, Cavallari M, El Daker S, Beddoe T, Theodossis A, Williams NK, Gostick E, Price DA, Soudamini DU, Voon KK, et al. Butyrophilin 3A1 binds phosphorylated antigens and stimulates human $\gamma \delta$ T cells. Nat Immunol. 2013; 14:908-916.

5. Wang H, Henry O, Distefano MD, Wang YC, Raikkonen J, Monkkonen J, Tanaka Y, Morita CT. Butyrophilin 3A1 plays an essential role in prenyl pyrophosphate stimulation of human V $\gamma 2$ V82 T cells. J Immunol. 2013; 191:1029-1042.

6. Thurnher M, Nussbaumer O, Gruenbacher G. Novel aspects of mevalonate pathway inhibitors as antitumor agents. Clin Cancer Res. 2012; 18:3524-3531.

7. Rincon-Orozco B, Kunzmann V, Wrobel P, Kabelitz D, Steinle A, Herrmann T. Activation of V gamma 9V delta 2 T cells by NKG2D. J Immunol. 2005; 175:2144-2151.

8. Nussbaumer O, Gruenbacher G, Gander H, Komuczki $\mathrm{J}$, Rahm A, Thurnher M. Essential requirements of zoledronate-induced cytokine and $\gamma \delta \mathrm{T}$ cell proliferative responses. J Immunol. 2013; 191:1346-1355.

9. Gertner-Dardenne J, Fauriat C, Orlanducci F, Thibult ML, Pastor S, Fitzgibbon J, Bouabdallah R, Xerri L, Olive D. The co-receptor BTLA negatively regulates human $\mathrm{V} \gamma 2 \mathrm{~V} \delta 2$ T-cell proliferation: a potential way of immune escape for lymphoma cells. Blood. 2013; 122:922-931.

10. Li W, Kubo S, Okuda A, Yamamoto H, Ueda H, Tanaka T, Nakamura H, Yamanishi H, Terada N, Okamura H. Effect of IL-18 on expansion of gammadelta T cells stimulated by zoledronate and IL-2. J Immunother. 2010; 33:287-296.

11. Tsuda J, Li W, Yamanishi H, Yamamoto H, Okuda A, Kubo S, Ma Z, Terada N, Tanaka Y, Okamura H. Involvement of CD56brightCD11c+ cells in IL-18-mediated expansion of human $\gamma \delta$ T cells. J Immunol. 2011; 186:2003-2012.

12. Raue HP, Brien JD, Hammarlund E, Slifka MK. Activation of virus-specific CD8+ T cells by lipopolysaccharideinduced IL-12 and IL-18. J Immunol. 2004; 173:6873-6881.

13. Raue HP, Beadling C, Haun J, Slifka MK. Cytokinemediated programmed proliferation of virus-specific CD8(+) memory T cells. Immunity. 2013; 38:131-139.

14. Zhang T, Kawakami K, Qureshi MH, Okamura H, Kurimoto M, Saito A. Interleukin-12 (IL-12) and IL-18 synergistically induce the fungicidal activity of murine peritoneal exudate cells against Cryptococcus neoformans through production of gamma interferon by natural killer cells. Infect Immun. 1997; 65:3594-3599.

15. Ardolino M, Azimi CS, Iannello A, Trevino TN, Horan L, Zhang L, Deng W, Ring AM, Fischer S, Garcia KC, Raulet DH. Cytokine therapy reverses NK cell anergy in MHCdeficient tumors. J Clin Invest. 2014; 124:4781-4794. 
16. Kunzmann V, Bauer E, Feurle J, Weissinger F, Tony HP, Wilhelm M. Stimulation of gammadelta $T$ cells by aminobisphosphonates and induction of antiplasma cell activity in multiple myeloma. Blood. 2000; 96:384-392.

17. Weninger W, Manjunath N, von Andrian UH. Migration and differentiation of CD8+ T cells. Immunol Rev. 2002; 186:221-233.

18. Rochman Y, Spolski R, Leonard WJ. New insights into the regulation of $\mathrm{T}$ cells by gamma(c) family cytokines. Nat Rev Immunol. 2009; 9:480-490.

19. Morita CT, Jin C, Sarikonda G, Wang H. Nonpeptide antigens, presentation mechanisms, and immunological memory of human Vgamma2Vdelta2 $\mathrm{T}$ cells: discriminating friend from foe through the recognition of prenyl pyrophosphate antigens. Immunol Rev. 2007; 215:59-76.

20. Toutirais O, Cabillic F, Le Friec G, Salot S, Loyer P, Le Gallo M, Desille M, de La Pintière CT, Daniel P, Bouet F, Catros V. DNAX accessory molecule-1 (CD226) promotes human hepatocellular carcinoma cell lysis by Vgamma9Vdelta2 T cells. Eur J Immunol. 2009; 39:1361-1368.

21. Chen L, He W, Kim ST, Tao J, Gao Y, Chi H, Intlekofer AM, Harvey B, Reiner SL, Yin Z, Flavell RA, Craft J. Epigenetic and transcriptional programs lead to default IFN-gamma production by gammadelta T cells. J Immunol. 2007; 178:2730-2736.

22. Yin Z, Chen C, Szabo SJ, Glimcher LH, Ray A, Craft J. T-Bet expression and failure of GATA-3 cross-regulation lead to default production of IFN- $\gamma$ by gammadelta $\mathrm{T}$ cells. J Immunol. 2002; 168:1566-1571.

23. Kannan Y, Yu J, Raices RM, Seshadri S, Wei M, Caligiuri MA, Wewers MD. I $\kappa \zeta$ augments IL-12- and IL-18mediated IFN-gamma production in human NK cells. Blood. 2011; 117:2855-2863.

24. Miyake T, Satoh T, Kato H, Matsushita K, Kumagai Y, Vandenbon A, Tani T, Muta T, Akira S, Takeuchi O. I $\kappa$ B $\zeta$ is essential for natural killer cell activation in response to IL-12 and IL-18. Proc Natl Acad Sci U S A. 2010; 107:17680-17685.

25. Xu D, Chan WL, Leung BP, Hunter D, Schulz K, Carter RW, McInnes IB, Robinson JH, Liew FY. Selective expression and functions of interleukin 18 receptor on Thelper (Th) type 1 but not Th2 cells. J Exp Med. 1998; 188:1485-1492.

26. Berg RE, Cordes CJ, Forman J. Contribution of CD8+ T cells to innate immunity: IFN-gamma secretion induced by IL-12 and IL-18. Eur J Immunol. 2002; 32:2807-2816.

27. Lauwerys BR, Renauld JC, Houssiau FA. Synergistic proliferation and activation of natural killer cells by interleukin 12 and interleukin 18. Cytokine. 1999; 11:822-830.

28. Micallef MJ, Ohtsuki T, Kohno K, Tanabe F, Ushio S, Namba M, Tanimoto T, Torigoe K, Fujii M, Ikeda M, Fukuda S, Kurimoto M. Interferon-gamma-inducing factor enhances $\mathrm{T}$ helper 1 cytokine production by stimulated human $\mathrm{T}$ cells: synergism with interleukin-12 for interferon-gamma production. Eur J Immunol. 1996; 26:1647-1651.

29. Barbulescu K, Becker C, Schlaak JF, Schmitt E, Meyer zum Buschenfelde KH, Neurath MF. IL-12 and IL-18 differentially regulate the transcriptional activity of the human IFN-gamma promoter in primary CD4+ $\mathrm{T}$ lymphocytes. J Immunol. 1998; 160:3642-3647.

30. Smeltz RB. Profound enhancement of the IL-12/IL-18 pathway of IFN-gamma secretion in human CD8+ memory T cell subsets via IL-15. J Immunol. 2007; 178:4786-4792.

31. Fehniger TA, Shah MH, Turner MJ, VanDeusen JB, Whitman SP, Cooper MA, Suzuki K, Wechser M, Goodsaid F, Caligiuri MA. Differential cytokine and chemokine gene expression by human NK cells following activation with IL-18 or IL-15 in combination with IL-12: implications for the innate immune response. J Immunol. 1999; 162:4511-4520.

32. Robinson D, Shibuya K, Mui A, Zonin F, Murphy E, Sana T, Hartley SB, Menon S, Kastelein R, Bazan F, O’Garra A. IGIF does not drive Th1 development but synergizes with IL-12 for interferon-gamma production and activates IRAK and NFkappaB. Immunity. 1997; 7:571-581.

33. Carter LL, Murphy KM. Lineage-specific requirement for signal transducer and activator of transcription (Stat)4 in interferon gamma production from CD4(+) versus CD8(+) T cells. J Exp Med. 1999; 189:1355-1360.

34. Ribeiro ST, Ribot JC, Silva-Santos B. Five layers of receptor signaling in $\gamma \delta$ T-Cell differentiation and activation. Front Immunol. 2015; 6:15.

35. Guo BL, Liu Z, Aldrich WA, Lopez RD. Innate anti-breast cancer immunity of apoptosis-resistant human gammadelta-T cells. Breast Cancer Res Treat. 2005; 93:169-175.

36. Zumwalde NA, Haag JD, Sharma D, Mirrielees JA, Wilke LG, Gould MN, Gumperz JE. Analysis of immune cells from human mammary ductal epithelial organoids reveals $\mathrm{V} \delta 2+\mathrm{T}$ Cells that efficiently target breast carcinoma cells in the presence of bisphosphonate. Cancer Prev Res (Phila). 2016; 9:305-316.

37. Corvaisier M, Moreau-Aubry A, Diez E, Bennouna J, Mosnier JF, Scotet E, Bonneville M, Jotereau F. V gamma $9 \mathrm{~V}$ delta $2 \mathrm{~T}$ cell response to colon carcinoma cells. J Immunol. 2005; 175:5481-5488.

38. Sicard H, Al Saati T, Delsol G, Fournie JJ. Synthetic phosphoantigens enhance human Vgamma9Vdelta2 $\mathrm{T}$ lymphocytes killing of non-Hodgkin's B lymphoma. Mol Med. 2001; 7:711-722.

39. Kabelitz D, Wesch D, Pitters E, Zoller M. Characterization of tumor reactivity of human $\mathrm{V}$ gamma $9 \mathrm{~V}$ delta 2 gamma delta T cells in vitro and in SCID mice in vivo. J Immunol. 2004; 173:6767-6776.

40. Liu Z, Guo BL, Gehrs BC, Nan L, Lopez RD. Ex vivo expanded human Vgamma9Vdelta2+ gammadelta-T cells 
mediate innate antitumor activity against human prostate cancer cells in vitro. J Urol. 2005; 173:1552-1556.

41. Yagita M, Huang CL, Umehara H, Matsuo Y, Tabata R, Miyake M, Konaka Y, Takatsuki K. A novel natural killer cell line (KHYG-1) from a patient with aggressive natural killer cell leukemia carrying a p53 point mutation. Leukemia. 2000; 14:922-930. 